\title{
The Effect of Working Capital Management on Profitability: The Case of Selected Manufacturing and Merchandising Companies in Hawassa City Administration
}

\author{
Ayneshet Agegnew \\ Lecturer, Accounting and Finance Department, College of Business and Economics, Wolaita Sodo University, \\ Wolaita, Ethiopia
}

\begin{abstract}
The purpose of this study is to investigate the effect of working capital management on profitability. The study aims to examine the statistical significance between component of working capital management and firm's profitability. In light of this objective the study adopted quantitative method of research approaches to test a series research hypothesis. Specifically, the study used survey of documentary analysis of companies' audited financial statements. Purposive sampling design was employed based on purposively of companies. Then companies were selected based on purposively from each company to avoid biases. Consequently, the study selected a sample of 5 (five) Manufacturing and 13(Thirteen) Merchandise companies for the period of seven years (2009-2015) with the total of 18 observations. Data was analyzed on quantitative basis using Pearson's correlation and pooled panel data regression models of cross-sectional and time series data were used for analysis. More over the study used gross operating profit as dependent profitability variable. Accounts receivable Days, inventory Period, and accounts payable Days and cash conversion cycle are used as independent variables. Also current ratio, firm size and sale growth as control variable The results showed that there is statistical significance negative relationship between profitability and working capital management. It means that, companies managers can create profits or value for their companies and shareholders by handling correctly the cash conversion cycle and keeping each different component of working capital to a possible optimum level. The researcher found that there is a significant negative relationship between liquidity and profitability. Moreover the study finds that there is a significance positive relationship between size and firm profitability. Meanwhile the study found that there is positive relationship between firm's growths and firm's profitability
\end{abstract}

Keywords: Working capital management, Profitability, Cash conversion cycle, Account Receivables, Inventory DOI: $10.7176 / \mathrm{RJFA} / 10-1-07$

\section{INTRODUCTION}

\subsection{Background of the study}

Working capital management is also one of the important parts of the financial management. It is concerned with short-term finance of the business concern which is a closely related trade-off between profitability and liquidity. Efficient working capital management leads to improve the operating performance of the business concern and it helps to meet the short-term liquidity. Hence, study of working capital management is not only an important part of financial management but also is overall management of the business concern. Working capital is described as the capital which is not fixed but the more common uses of the working capital is to consider it as the difference between the book value of current assets and current liabilities.( C.Paramasivan and T.Subramian (2009).

Wang(2002), shin and Soenen(1993), Lazaridis and Tryfomids(2006), Falope and Ajilore (2009) have shown that working capital management has an effect on profitability of firms own that working capital management has an effect on profitability of a firm and proper estimation of working capital is difficult task for the management because amount of working capital varies across firms over the periods depending up on the nature of business, scale of operation, production cycle, credit policy, availability of raw materials, etc. For this reason significant amount of funds is necessary to invest permanently in the form of funds is necessary to invest permanently in the form of varies current assets. For instance, due to time lag between sale of goods and their actual realization in cash, adequate amount of working capital is always required to be made available for maintaining the desired level of sale ( Blinder \& L.J. Maccini 1991).

The working capital management practices also examine the impact of aggressive/conservative. Moderate working capital investment and finance policy. Wajahnani \&syed(2010),Vishnani \& Shah B(2007) argue that working capital is just an idle resource with it so they advised companies to follow zero working capital policy but such a policy is very risky because it reduces the liquidity and it might leads to a default. Other researchers support companies to have working capital policy because believe that proper management of component of working capital can balance cost and benefits of the company and it will reduce the risk of default by raising the level of liquidity. Companies can choose among three different types of working capital i.e. aggressive, conservative, and moderate but their choice depends on their desired level of liquidity and risk. In modem financial management, administration of working capital is an important and challenging task due to high 
proportion of working capital in a business and some of its peculiar characteristics.

The management of current assets (normally converted into cash within an accounting year) and current liabilities (generally discharged within a year) and the interrelationship that exists between them may be termed as working capital management.

Excessive levels of current assets may have a negative effect on the firm's profitability whereas a low level of current assets may lead to lower level of liquidity and stock outs resulting in difficulties in maintaining smooth operations (Van Horne and Wachowicz, 2004). Traditional concept of working capital is the different between assets and current liabilities. Thus working capital management is an attempt to manage and control the current assets and the current liabilities in order to maximize profitability and proper level of liquidity in business.

Liquidity and profitability are two important and major aspects of corporate business life (Dr. K.S. Vataliya, 2009). The problem is that increasing profits at the cost of liquidity can bring serious problems to the firm. Therefore, there must be a trade-off between these two objectives (liquidity and profitability) of firms. One objective should not be at the cost of the other because both have their own importance.

If firms do not care about profit, they cannot survive for a longer period. In other word, if firms do not care about liquidity, they may face the problem of insolvency or bankruptcy. For these reasons managers of firms should give proper consideration for working capital management as it does ultimately affect the profitability of firms.

As a result company can achieve maximum profitability and can maintain adequate liquidity with the help of efficient and effective management of working capital. Inefficient financial management including working capital management may damage business enterprise's profitability (Gebrehiwot \& Wolday, 2006). The efficient management of working capital is a fundamental part of the overall corporate strategy to create shareholders value (Nazir and Afza, 2008). In addition, efficient working capital management leads to improve the operating performance of the business concern and it helps to meet the short term liquidity (C. Paramasivan $T$. Subramanian, 2009). Therefore firms try to keep an optimal level of working capital that maximizes their value (Deloof, 2003). In addition to that, the effective working capital management is very important because it affects the performance and liquidity of the firms (Taleb et al., 2010). The main objective of working capital management is to reach optimal balance between working capital management components (Gill, 2011).Large inventory and generous trade credit policy may lead to high sales. Large inventory also reduces the risk of a stock-out. Trade credit may stimulate sales because it allows a firm to access product quality before paying .(Raheman and Nasr, 2007).

Another component of working capital is accounts payables, Raheman and Nasr (2007) indicated that delaying payment of accounts payable to suppliers allows firms to access the quality of obtaining products and can be inexpensive and flexible source of financing. On the other hand, delaying of such payables can be expensive if a firm is offered a discount for the early payment. By the same taken, uncollected accounts receivables can lead to cash inflow problems for the firm.

A popular measure of working capital management is the cash conversion cycle that is the time span between the expenditure for the purchase raw materials and the collection of sales of finished goods. Deloof (2003) found that the longer the time lags, the larger the investment in working capital, and also along cash conversion cycle might increase profitability because it leads to higher sales. However, corporate profitability might decrease with the cash conversion cycle, if the costs of higher investment in working capital rise faster than the benefits of holding more inventories or granting more trade credit to customers. And the main cause of the failure of a business enterprise has been found to be the shortage of working capital, their mishandling, mismanagement of working capital and under utilization of capacity ( Vataliva,2009).In general, working capital management is not only improving financial performance in today's cash-strapped and uncertain economy, but it is the question of meeting firm's day to day operation. Therefore, it is a significant issue to know and understand the effect of working capital management and its influence on firm's profitability. Also, several research works have identified the effect of working capital management on the profitability of organizations, but no significant work appear to have been done on the profitability manufacturing and merchandise company emerging economics like Ethiopia. This limited evidence in the context of Ethiopia along with the importance of working capital management invite for research on their impacts on firm's profitability. Considering of the above points, the general objective of the study will be to examine the effect of working capital management on profitability of Manufacturing and Merchandise Company in Hawassa city Administration, Ethiopia.

\section{2.Statment of the Problem}

The effectiveness of working capital management can have a significant impact on both the liquidity and profitability of a company (Shin and Soenen, 1998). For the liquidity, lack of working capital can account for inefficiencies in a company's operation when it is not able to pay off its due obligations. On the other hand, without sufficient working capital, the company will not either be able to provide goods or services required to 
customers due to lack of money to buy materials for producing goods. The company's profitability can be jeopardized as a result.

In addition, Lamberson (1995) showed that working capital management is of importance in managing financial aspect of a company. Many financial managers are finding it difficult to identify the important drivers of working capital management that can enhance their company profitability. Most researchers find a strong negative cause-and-effect relationship between number of days of inventories, number of days of accounts receivable and cash conversion cycle with the corporate profitability (Shin and Soenen, 1998; Deloof, 2003; Raheman and Nars 2007); and a positive relationship between number of days of accounts payable with the corporate profitability (Lazaridis and Tryfonidis, 2006). In contrast, there are few researchers who provided different results. For example, Nobanee (2009) concludes a positive relationship between cash conversion cycle, number of days accounts receivable and number of days inventory with ratio of the firm's operating income to sales whereas number of days accounts payable has significant negative effect on the firm's performance.

Every firm is required to maintain a balance between profitability and liquidity while conducting its day to day operations. As inadequate amount of working capital impairs a firm's liquidity, holding of excess working capital results in the reduction of the profitability.

Working capital management is concerned with two decision areas: determination of appropriate level of investment in current assets and decision as to what method of financing to use and to obtain funds for this investment. They are part of investment and financing decision respectively.

Pass and Pike (1987) emphasized that short term finance area particularly working capital management was given very less attention in contrast to long term investment even if it plays a very vital and important role in the growth of firm and in enhancement of profitability. Deficiency in the planning and control of working capital management is one of the main causes of business failure and it is a neglected subject which has been too little investigated or written about. The two main objectives need to be satisfied by working capital management is liquidity and profitability but there should be a trade-off between these two objectives. However, the identification of such relationships have not been identified for Ethiopia manufacturing and merchandising companies is limited when it comes to Hawassa city administration, to the best of the researcher's knowledge, there has been no research done regarding the effect of working capital management on profitability of companies in Hawassa and its surrounding. On top of that, there are a number of Manufacturing and Merchandising companies cropping out at different part of the country including Hawassa city Administration. Currently there are around 5 manufacturing and 13 Merchandising companies operating in Hawassa city Administrations and many of the companies have been operating for more than 10 years. Therefore, it is right time to analyze the effect of working capital management on profitability of the companies to guide them on the right truck of operation. Therefore, this study attempts to analyze the effect of working capital management on profitability of Manufacturing and Merchandising enterprises in Hawassa City Administration.

\subsection{Objectives of the Study}

\subsubsection{General Objective of the Study}

The general objective of the study is to analyze the effect of working capital management on profitability of Manufacturing and Merchandising enterprises in Hawassa city Administration.

\section{3.2. Specific Objectives}

The specific objectives of the study are :

1) To evaluate the trend of the variables (both dependent and independent) considered in this study over the study period ( 2009-2015 G.C)

2) To analyze the relationship between profitability and the following determinants of profitability namely Inventory period, Average collection period, Average payment period, and Cash conversion cycle.

3) To identify the variables with significant impact on profitability from the potential determinants.

\subsection{Hypothesis of the study}

After reviewing different literature the following five directional Hypotheses have been formulated:

HI " 1 " : Inventory period has statistically significant negative effect on profitability.

HI "'2": Account receivable period has statistically significant negative effect on Profitability.

HI ' 3"' cash conversion cycle has statistically significant negative effect on profitability.

HI "4" : Account payable period has statistically significant positive effect on profitability..

\subsection{Significance of the study}

The study will provide relevant information about the effect of working capital management on profitability for management of the related companies. In addition, the study will have vital use for policy makers to consider the identified factor and to take corrective measure that promote manufacturing and merchandising sector 
profitability. It lays foundation for future study on stated area.

\subsection{The scope of the study}

This study focuses on the impact of working capital management component on the firm's profitability, from a period 2009 -2015, So selecting seven years because limited number of firms with an operating life of more than seven years although there is a lot of business operation which existing in Ethiopian Hawassa this study focus on manufacture sectors and merchandise sector. The decision to use manufacturing and merchandise companies on the following two aspects that enhance the validity of the study. First, both companies represent an appropriate sample in order to analyze working capital management. Because all of four components working capital (inventory, cash conversion cycle account receivable and payable) usually play important roles in the manufacturing and merchandise sector comparability of the sample companies will be enhanced.

\subsection{Organization of the study}

The study will be organized in five chapters. The first chapter will deal with introduction, statement of the problems, objectives of the study, research hypothesis, significance of the study, and scope and limitation of the study. In the second chapter, different literature that relates to the topics of the study will be reviewed and presented. In the third chapter, the research methodology including the population and sampling procedure, data and data collection instrument, data analysis, Choice of Variable and techniques used in data collection and analysis will be presented. Chapter four is about data presentation, analysis, and discussion. Finally chapter five deals with the summary of finds, conclusion and recommendation.

\section{LITERATURE REVIEW}

\subsection{Introduction}

The purpose of this chapter is to review the related literature on working capital management and profitability measures of a firm. Hence, the chapter is arranged into three sections. The first section presents the theoretical literature review of working capital management while the second section reviews the empirical literature pertaining to working capital management. The third section presents summary on the literature review and identifies the knowledge gap that this study attempts to fill in.

\subsection{Theoretical Literature Review}

\subsubsection{Definition and Concept of Working Capital}

The term working capital originated with the old Yankee peddler, who would load up his wagon with goods and then go off on his route to peddle his wares. The merchandise was called working capital because it was what he actually sold, or "turned over," to produce his profits. The wagon and horse were his fixed assets. He generally owned the horse and wagon, so they were financed with "equity" capital, but he borrowed the funds to buy the merchandise. These borrowings were called working capital loans, and they had to be repaid after each trip to demonstrate to the bank that the credit was sound. If the peddler was able to repay the loan, then the bank would make another loan, and banks that followed this procedure were said to be employing "sound banking practices" (Brigham and Houston, 2003).

The concept of working capital was, perhaps, first evolved by Marx (1867), thought in a somewhat different form. Marx used the term 'variable capital' meaning outlays for payrolls advanced to workers before the goods they worked on were complete. He contrasted this with 'constant capital', which according to him, is nothing but 'dead labor', i.e. outlays for raw materials and other instruments of production produced by labor in earlier stages which are now needed live labor to work with in the present stage. This 'variable capital' was the wage fund which remains blocked in terms of financial management, in work-in-process along with other operating expenses until it is released through sale of finished goods. Although Marx did not mention that workers also gave credit to the firm by accepting periodical payment of wages which funded a portion of work-in-process, the concept of working capital, as we understand today, was embedded in his 'variable capital' The working capital of a business enterprise can be said as portion of its total financial resources which is put to a variable operative purpose (Brigham and Gapenski, 1996).

The facilities that are necessary to carry on the productive activity and represented by fixed assets investment (i.e. non-current asset investment) are to be operated by working capital. In an annual survey of industries by government of India (2008), the working capital is defined as "stocks of raw materials, stores, fuels, semi-finished goods, including work in progress and finished products; cash in hand and at the bank and the algebraic sum of sundry creditors as represented by (a) outstanding factor payments e.g. rent, wages, interest and dividends; (b) purchase of goods and services; (c) short term loan and advances and sundry debtors comprising amounts due to the factory on the account of sale of goods and services and advances towards tax payments.

The term "working capital" refers to the investment in current assets which are required to carry on the operations of the business (Firer et al, 2008). Kaveri (1985) refers to it as the difference between current assets 
and current liabilities. Managing the firm's working capital is a day-to-day activity that ensures that the firm has sufficient resources to continue its operations and avoid costly interruptions.

The term capital is used in deferent ways in economics and in finance (Bhattacharyya, 1987). In economics, the term capital represents goods consisting of a great variety of things, namely, machines of various kinds, plants, houses, tools, raw materials and goods-in-process. A finance manager of a firm looks for these things on the assets side of the balance sheet. For capital, he turns his attention to the other side of the balance sheet and never commits the mistake of adding the two together while taking the census of total capital of the business. Although economists regard fixes capital as what is represented by long-term assets, a finance manager defines fixed capital as that having long term maturity.

Working capital is defined as "the excess of current assets over current liabilities and provisions". However, as per accounting terminology, it is difference between the inflow and outflow of funds. In Arnold (2008) working capital is defined as it includes "stocks of materials, fuels, semi-finished goods including work-inprogress and finished goods and by-products; cash in hand and bank and the algebraic sum of various creditors as represented by outstanding factory payments e.g. rent, wages, interest and dividend; purchase of goods and services; short-term loans and advances and sundry debtors comprising amounts due to the factory on account of sale of goods and services and advances towards tax payments".

On the other hand, the term working capital is often referred to "circulating capital" which is frequently used to denote those assets which are changed with relative speed from one form to another i.e., starting from cash, changing to raw materials, converting into work in-progress and finished products, sale of finished products and ending with realization of cash from debtors (Weston and Brigham, 1977). Further, Shin and Soenen (1998) defined working capital as a "time lag between the expenditure for the purchase of materials and the collection for the sale of the finished products". In summary, working capital means the funds (i.e. capital) available and used for day to day operations of an enterprise. It consists broadly of that portion of assets of a business which are used in or related to its current operations. Further, it refers to funds which are used during an accounting period to generate a current income of a type which is consistent with major purpose of a firm existence. In light of the above definition of working capital the following discussions present components of working capital, types of working capital, factors determining working capital requirement, working capital management, working capital policy, profitability and liquidity measures and trade-off between liquidity and profitability in an orderly manner.

\subsubsection{Nature of Working Capital}

While assets represent wealth of the firm, firms may not want to hold many of the assets appearing on the balance sheet (Bhattacharyya, 1987; Sebhatleab, 2002). In a perfect world, the production process takes very little time to convert the raw materials to finished products which gets sold immediately in cash when it completed the production process; and the input market is so perfect that any amount of raw material is available at any time at a fixed price. There is no uncertainty, no transaction costs, and no scheduling costs of production or constraints of technology. The unit costs of producing goods will not change with the amount produced. Firms can borrow and lend at the same interest rate. Capital, labor and product markets are perfectly competitive and reflect all available information. In such an ideal world firms may like to hold fixed assets like plant and machinery which produce goods and services; the sales of which generate a profit; current assets like accounts receivable, inventories or even cash are not likely to be held in the business.

However, this is an ideal situation difficult to have in the real world. Instead, the production process takes quite some time; the finished products are not sold so quickly which means a quantity of stocks remains in the warehouse. Moreover, the sales are not always in cash; some amount of credit has to be given and the input markets are so uncertain, so that, firms have to keep a certain amount of safety stock all the time.

These 'non-ideal' conditions thus generate certain assets which are called current assets and the levels of these assets make a significant part of a firm's investment in its total assets. Current assets, therefore, block the funds which should have been otherwise available for meeting working expenses. Each and every current asset of a firm is, thus, nothing but congealed fund for working expenses. And because business is a continuous process, every cycle of operation generates these current assets which need to be funded for immediate financing of working expenses. This funding for working expenses is done by, what we popularly call, working capital.

\subsubsection{Components of Working Capital}

According Paramasivan and Subramanian (2009). There are two concepts of working capital known as gross and net. Gross working capital (GWC): Gross working capital generally deals with overall corporate assets. It is also the total cash, and cash equivalent that a business has on-hand to run the business. Cash equivalents may include inventory, account receivable and investments, on marketable securities, which may be liquidated within the calendar year (Paramasivan and Subramanian, 2009).

Generally, gross working capital is simply called as the total current assets of a firm. Net working capital (NWC): it's the amount of assets or cash that remain after subtracting a company's current liabilities which refers to the claims of outsiders which are expected to mature for payment within an accounting year and include 
creditors for goods, bills payable, bank overdraft and accrued expenses from its total current asset (Brealey and Myers, 2006). This can be mathematically presented as:

Working capital $=$ Current assets- current liabilities

\subsubsection{Types of Working Capital (WC)}

Most businesses experience seasonal or cyclical fluctuations. For example, construction firms have peaks in the spring and summer, retailer's peak around Christmas, and manufacturers who supply both construction companies and retailers follow similar patterns. Similarly, all businesses must build up current assets when the economy is strong, but they then sell off inventories and reduce receivables when the economy slacks off. Hence, based on time, working capital may be classified into two important types as permanent and temporary working capital (Paramasivan and Subramanian, 2009) and briefly discussed below.

Permanent Working Capital: it's also known as fixed working capital and it refers to a minimum amount of investment in all working capital which is required at all times to carry out minimum level of business activities (Brigham and Houston, 2003). In other words, it represents the current assets required on a continuing basis over the entire year. Further, working capital has a limited life and usually not exceeding a year, in actual practice some part of the investment in that is always permanent. Since firms have relatively longer life and production does not stop at the end of a particular accounting period some investment is always locked up in the form of raw materials, work-in-progress, finished stocks, book debts and cash. Investment in these components of working capital is simply carried forward to the next year. This minimum level of investment in current assets that is required to continue the business without interruption is referred to as permanent working capital (Fabozzi and Peterson, 2003 p. 679). It's financed through long term debt and common stock.

Temporary Working Capital: it's also known as the circulating or transitory working capital. This is the amount of investment required to take care of the fluctuations in the business activity. Fabozzi and Peterson (2003 p. 678) they defined as a rises of working capital from seasonal fluctuations in a firm's business. Because firms do not have to maintain this form of working capital throughout in the year, or year after year, it may be better to use short-term ( bank credit) rather than log-term sources of capital to satisfy temporary needs. In other words, it represents additional current assets required at different times during the operating year. For example, extra inventory has to be maintained to support sales during peak sales period (seasonal working capital).

Similarly, receivable also increase and must be financed during period of high sales. On the other hand investment in inventories, receivables and the like will decrease in periods of depression (special working capital). Temporary working capital fluctuates over time with seasons and special needs of firm operations, whereas, permanent $\mathrm{WC}$ changes as firms sizes increases overtime. Further, temporary $\mathrm{WC}$ is financed by short term debt.

\subsubsection{Working capital policy}

Working capital policy can be best described as a strategy which provides the guideline to manage the current assets and current liabilities in such a way that it reduces the risk of default (Afza and Nazir, 2007). Working capital policy is mainly focusing on the liquidity of current assets to meet current liabilities. Liquidity is very important because, if the level of liquidity is too high then a company has lot of idle resources and it has to bear the cost of these idle resources. However, if liquidity is too low then it will face lack of resources to meet its current financial liabilities (Arnold, 2008). Current assets are key component of working capital and the WCP also depends on the level of current assets against the level of current liabilities (Afza and Nazir, 2007). On this base the literature of finance classifies working capital policy into three categories as defensive or hedging, aggressive and conservative working capital policy (Arnold, 2008 pp.535-36) and discussed as follows:

Defensive policy:

Company follows defensive policy by using long term debt and equity to finance its fixed assets and major portion of current assets. Under this approach, the business concern can adopt a financial plan which matches the expected life of assets with the expected life of the sources of funds raised to finance assets (Paramasivan and Subramanian, 2009). Inventory expected to be sold in 30 days could be financed with a 30-day bank loan; a machine expected to last for 5 years could be financed with a 5-year loan; a 20-year building could be financed with a 20 year mortgage bond; and so forth (Weston and Brigham, 1977, P. 716). Defensive policy reduces the risk by reducing the current liabilities but it also affects profitability because long term debt offers high interest rate which will increase the cost of financing (Arnold, 2008 p.530). This means a company is not willing to take risk and feel it appropriate to keep cash or near cash balances, higher inventories and generous credit terms. Mostly companies that are operating in an uncertain environment prefer to adopt such a policy because they are not sure about the future prices, demand and short term interest rate. In such situation it is better to have a high level of current assets. Which means, keeping higher level of inventory in the stock, to meet sudden rise in demand and to avoid the risk of stoppage in production.

This approach gives a longer cash conversion cycle for the company. It also provides the shield against the financial distress created by the lack of funds to meet the short term liability but as the researcher discussed earlier long term debt have high interest rate which will increase the cost of financing. Similarly, funds tied up in 
a business because of generous credit policy of company and it also have opportunity costs. Hence, this policy might reduce the profitability and the cost of following this policy might exceed the benefits of the policy (Arnold, 2008 p.530).

Aggressive policy: Companies can follow aggressive policy by financing its current assets with short term debt because it gives low interest rate. However, the risk associated with short term debt is higher than the long term debt. Paramasivan and Subramanian (2009) pinpointed that in Aggressive policy the entire estimated requirement of current assets should be financed from short-term sources and even a part of fixed assets financing be financed from short-term sources. This approach makes the finance mix more risky, less costly and more profitable. Furthermore, few finance managers take even more risk by financing long term asset with short term debts and this approach push the working capital on the negative side.

Managers try to enhance the profitability by paying lesser interest rate but this approach can be proved very risky if the short term interest rate fluctuates or the cash inflow is not enough to fulfill the current liabilities (Weston and Brigham, 1977, P. 716). Therefore, such a policy is adopted by the company which is operating in a stable economy and is quite certain about future cash flows. A company with aggressive working capital policy offers short credit period to customers, holds minimal inventory and has a small amount of cash in hand. This policy increases the risk of default because a company might face a lack of resources to meet the short term liabilities but it also gives a high return as the high return is associated with high risk (Arnold, 2008, p.536).

Conservative policy: Some companies want neither to be aggressive by reducing the level of current assets as compared to current liabilities nor to be defensive by increasing the level of current assets as compared to current liabilities. So, in order to balance the risk and return these firms are following the conservative approach. It is also a mixture of defensive WCP and aggressive WCP. In these approach temporary current as sets, assets which appear on the balance sheet for short period will be financed by the short term borrowings and long term debts are used to finance fixed assets and permanent current assets (Weston and Brigham, 1977, p. 718). Thus, the follower of this approach finds the moderate level of working capital with moderate risk and return. It is called as "low profit low risk" concept (Paramasivan and Subramanian, 2009). Moreover, this policy not only reduces the risk of default but it also reduces the opportunity cost of additional investment in the current assets.

On the other hand apart from the above points the level of working capital also depends on the level of sale, because, sales are the source of revenue for every companies. Sales can influence working capital in three possible ways (Arnold, 2008 p.534-35).

-As sales increase working capital will also increase with the same proportion so, the length

of cash conversion cycle remains the same.

-As the sales increase working capital increase in a slower rate.

-As the sales increase the level of working capital rises in misappropriate manner i.e. the working capital might raise in a rate more than the rate of increased in the sale.

Company with stable sale or growing sale can adopt the aggressive policy because it has a confidence on its future cash inflows and is confident to pay its short term liabilities at maturity. On the other hand a company with unstable sale or with fluctuation in the sale can't think of adopting the aggressive policy because it is not sure about its future cash inflows. In such a situation adoption of aggressive policy is similar to committing a suicide. Hence, searching other method might be the best choice.

\subsubsection{Short-term Financing}

Every business has several options when it decides to aggregate short-term financing. According to Gitman (2009) the financing of WC enhances the composition and the structure of the business financing in terms of short-term and long-term aspects. Afzar and Nazir (2008) investigated the traditional relationship between working capital management policies and a firm's profitability in their quantitative study for a sample of 204 non-financial firms listed on Karachi Stock Exchange (KSE) for the period 1998-2005.The study found significant difference among their working capital requirements and financing policies across different industries. Moreover, regression result found a negative relationship between the profitability of firms and degree of aggressiveness of working capital investment and financing policies. They suggested that managers could increase value if they adopt a conservative approach towards working capital investment and working capital financing policies (Shah and Sana, 2006).

Efficient management of working capital plays an important role of overall corporate strategy in order to create shareholder value. Working capital is regarded as the result of the time lag between the expenditure for the purchase of raw material and the collection for the sale of the finished goods.

The way of working capital management can have a significant impact on both the liquidity and profitability of the company (Shin and Soenen, 1998). The main purpose of any firm is maximizing profit. But, maintaining liquidity of the firm is also an important objective. The problem is that increasing profits at the cost of liquidity can bring serious problems to the firm. Thus, strategy of the firm must be balance between these two objectives. Because the importance of profit and liquidity are the same so, objective should not be at cost of the other. If profit is ignored, we cannot survive for a longer period. Conversely, if we do not care about liquidity, 
we may face the problem of insolvency. For these reasons working capital management should be given proper consideration and will ultimately affect the profitability of the firm.

\subsubsection{Profitability and its measure}

There are many different measurements of firm profitability among the researchers who studied the relation between WCM and firm profitability. The simplest form among these measurements is Return on Assets (ROA), which is measured by dividing net income with total assets. This is used by Sharma and Kumar (2011), Falope and Ajilore (2009) Wang (2002),Samiloglu and Demirgunes (2008), Garcia-Teruel and Martinez-Solano (2007), Nazir and Afza (2009) and Karaduman et al. (2011).According to Padachi et al. (2006) ROA is a good measure for firm profitability, because it relates the profitability of a company with its asset. Padachi et al. (2010) uses gross operating profit divided by total assets. Zariyawati et al. (2009) and Shin and Soenen (1998) used almost the same measurement, the only difference is that they used gross operating profit before depreciation divided by total assets.Shin and Soenen (1998) also used a second measurement of firm profitability, which is gross operating profit before depreciation divided by net sales, but this measurement is not used by any other researcher.

The last main measurement is gross operating profit before depreciation and amortization divided by total assets minus financial assets. This measurement is used by Deloof (2003), Raheman and Nasr (2007) and Lazaridis and Tryfonidis (2006). This measurement is not used by Sharma and Kumar (2011), due to the unavailability of such data regarding Indian firms in their financial disclosure.

\subsubsection{Determinants of profitability}

\subsubsection{Operating and cash conversion cycle}

A distinction between operating cycle and cash conversion cycle Short-term finance is concerned with shortterm operating activities such as buying materials, paying cash for purchases, manufacturing the product, selling the product or collecting cash. These activities create patterns of cash inflows and cash outflows that are both unsynchronized and uncertain. They are unsynchronized because the payment of cash for raw materials does not happen at the same time as the receipt of cash from selling the product. Additionally, those activities are uncertain since future sales and costs are both known with uncertainty.

Figure 2.1 Cash flow time line and the short-term operating activities typical Manufacturing firm Raw materials purchased

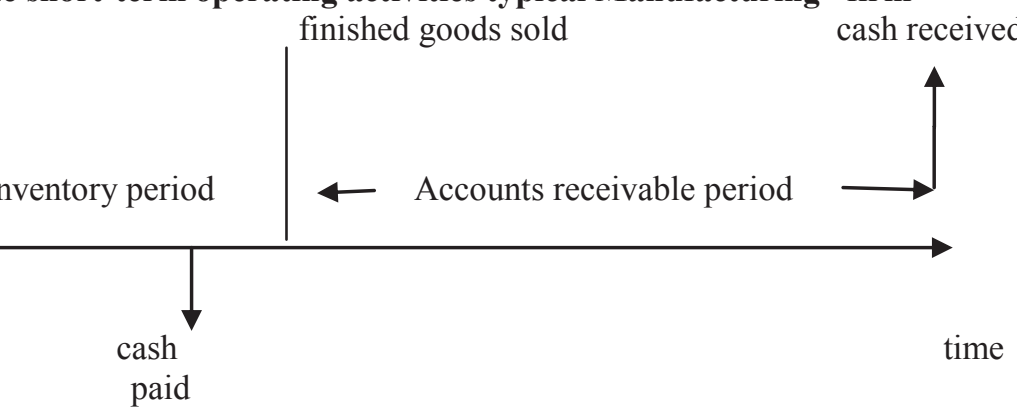

Firm received

paid

time

Source : Hiller et al, (2010)

The cash flow time line depicts an operating cycle and a cash conversion cycle. Operating cycle is the interval between the order of inventory stock and the date when cash is collected from receivables. In the mean time, cash conversion cycle begins when the company pays cash to suppliers for the materials purchased and ends when cash is collected from customers for credit sales. (Hillier et al, 2010, p.724). In general, cash conversion cycle is computed as operating cycle minus accounts payable period. Alternatively, cash conversion cycle is the sum of inventory period and accounts receivable period less accounts payable period. Raw material purchased Order placed Stock arrive Inventory period Finished goods sold Accounts receivable period Cash received Time Account payable period Cash paid for materials Firm receives invoice Operating cycle Cash conversion cycle.

Cash Conversion Cycle $=$ Operating Cycle - Accounts Payable Period

$=($ Inventory Period + Accounts Receivable Period $)-$ Accounts Payable Period .

Cash conversion cycle tells us how cash is moving through a company in terms of duration.

The cycle starts with a cash outflow by which the company pays back to suppliers for obtaining raw materials then ends with a cash inflow when receiving money back from its customers for selling its goods or services. In other words, the cycle indicates the number of days it takes the company to convert its operating activities requiring cash into cash returns.

Therefore, a downward trend in this cycle is a positive signal whereas a negative signal is blamed for the upward one. When the cash conversion cycle shortens, cash becomes free for other usages such as investing on equipment and infrastructure or innovating manufacturing and selling processes. In contrast, when the cash conversion cycle lengthens, cash tied up in the firm's operation activities, leaving little chance for other investments of this cash flow. In an ideal case, a company should attempt to keep its cash conversion cycle as close to zero as possible. In other words, the company is trying to maintain its production to be internally 
financed. However, the cash tied up in inventory and receivables will be almost practically exceed the cash supplied by creditors and accrued liabilities (Melicher \& Leach, 2009, p.184).

Therefore efforts must be made to keep at minimum level. If the payment period is longer than the sum of inventory and receivable period, it results in a negative Cash Conversion Cycle. But the chances of its occurrence are rare (Gitman 1991). A negative CCC indicates the number of days a company has received cash from sales before it must pay its suppliers (Hutchison et al., 2007).Gentry et al., (1990) developed a weighted cash conversion cycle, which scales the timing by the amount of funds in each step of cycle. However this measure cannot be used because the information required for the calculation of this measure is not available for Pakistani listed firms.

Cash conversion cycle is deemed as the most dominant and prevalent measurement for efficiency of working capital management (Gill, Biger and Mathur, 2010; and Nobanee, Abdullatif and AlHajjar, 2011). In addition, CCC has also been adopted by other researchers as one of the measurements of WCM in their study such as Moss and Stine (1993); Eljelly (2004); Lazaridis and Tryfonidis (2006); Uyar (2009); Zariyawati, Annuar, Taufiq and Abdul Rahim (2009); Nor Edi Azhar and Noriza (2010); Charitou, Elfani and Lois (2010); Karaduman, Akbas, Caliskan andDurer (2011); and Charitou, Lois and Halim (2012). According to Deloof (2003); Zariyawati, Annuar, Taufiq and Abdul Rahim (2009); Gill, Biger and Mathur, (2010), for a comprehensive determination of WCM, CCC is applied that is computed based on [number of days accounts receivable $(\mathrm{ARD})+$ number of days inventory (INV) -number of days accounts payable (AP)]. It is apparent that cash cycle has negative impact on profitability, and thus, this research also proposes the same relationship between cash conversion cycle and profitability.

\subsubsection{Inventory Period}

The word "inventory" has been defined in many ways. Ballou (2004) defines inventories as stockpiles of raw materials, supplies, components, work in process, and finished goods that appear at numerous points throughout a firm's production and logistics channel's. According to Chase, Jacob and Aquiline (2004) inventory is the stock of any item or resource used in an organization. An inventory system is the set of policies and controls that monitor levels of inventory and determine what levels should be maintained, when stocks should be replenished, and how large orders should be.

Finally, Pycraft et al (2004) define inventory or stock as the stored accumulation of materials resources in a transformation system. Inventory is a barometer of manufacturing efficiency. Excess level of inventories decreases cash flow while on the other side too small level of inventories may result in decreasing sales. Inventory turnover and days inventory held are two measures of inventory management. (White, 2008). Inventory of a firm can be divided into three groups which include raw material, work in process and finished goods (Horne, 1995).

The work in process inventory can only be reduced to a certain level by speeding up manufacturing processes (Weston and Copeland, 1986). The other types of two inventories are however, not unavoidable (Horne 1995). Inventory is an important component of working capital. The higher and lower level of inventories can have their impact on the returns or profitability of firm. According to Chen et.al., $(2005,2007)$, the public companies which have very high level of inventories have experienced very low level of returns but in general, lower level of Inventories do not results in higher returns. The study conducted by Lai (2006) indicated that, when the market downgrades higher inventory firms, it results in decrease in inventory levels by the firms and vice versa. Another study conducted by Gaur et al. (2005) also examined inventory behavior in retail business firms. A model was proposed by them which explained the differences in inventory turnover across firms. They created an adjusted inventory turnover measure for specifically retail business firms. The results of the study found that there was a negative relationship between inventory turnover and gross profit margin while positive relationship between inventory turnover and capital intensity and sales surprise for the retail business firms. Inventory Turnover in Days which is also called as inventory conversion period is the average length of time required for conversion of raw materials into finished goods and then in selling those goods. This variable helps in evaluating the efficiency in inventory management policy of the firm. It is expected that this variable has also a negative relationship with the profitability. If the firms take more time in selling inventory which means inventories are not getting convert into sales, will decrease the profitability of firms.

Inventory is an important and valuable asset. It constitutes substantial portion of the total current assets of a business. Inventory covers a wide variety of items which are meant to be procured, ,used upe and sold in an ordinary course of business. It covers the whole range of items starting from input of material and ending with output of finished products. According to Josh (2000) the item forming inventory can be classified into three categories: (1) raw materials, (2)work-in-process (WIP) and (3) finished goods. Raw material inventory represents the item of basic inputs which are yet to be processed into final product. Work-in process covers all items which are at various stages of production processes. These items have ceased to be raw material but have not developed into final products and are at various stages of semi-finished levels. Finished goods inventory consists of the final products which are awaiting sale. According to Hugo et al (2002) the aim of inventory 
management is to hold inventories at the lowest possible costs .Josh (2000) enumerates the objectives of inventory management as fellows; To reduce cost of holding stock so that investment in stock outs (running out of stock) production cycle operates smoothly. To persuade the business to reduce the levels of inventory whereas one prompts it to increase the same. When making decisions on inventory, management has to find a compromise between the different cost components, such as the cost of supplying inventory, inventory-holding costs and cost resulting from insufficient inventories.

Starr and Miller (1962) identify three motives for holding inventories which are similar to Keynes three motives for holding cash. The transaction motives which emphasizes the need to maintain inventories to facilitate smooth production and sales operation, the precautionary motive which necessitate holding of inventories to guard against the risk of unpredictable changes in demand and supply forces and other factors; and the speculative motive which influence the decision to increase or reduce inventory levels to take advantage of price fluctuations. According to Wild (2002) inventory controls is the activity which organizes the availability of items to the customers. It coordinates the purchasing, manufacturing and distribution function to meet the marketing needs.

This role includes the supply of current sale items, new products, consumables: spare parts, obsolete items and all other supplies. Inventory enables a company to support the customer service, logistic or manufacturing activities in situation where purchasing or manufacturing of the items is not able to satisfy the demand. Lack of satisfaction could arise either because the speed of purchasing or manufacturing is too protracted, or because quantities cannot be provided without stocks. Clodfelter (2003) adds that a good inventory control system offers the following benefits as the proper relationship between sales and inventory can better be well maintained. Without inventory control procedures in place, the stores department can become overstocked or under stocke; next, inventory control systems provide a business with information needed to take markdowns by identifying slow-selling merchandise. Discovering such items early in the season will allow a business to reduce prices or make a change in marketing strategy before consumer demand completely disappear Merchandise control system allows buyers to identify best-sellers early enough in the season so that re-orders can be placed to increase total sales for the store or department. Merchandised shortages and shrinkages can be identified using inventory control systems. Excessive shrinkage will indicate that more effective merchandising controls need to be implemented to reduce employee theft or shoplifting. Emphasizing the pertinence of the topic, Gourdin (2001) notes that inventory is one area of logistics that has received great deal of management's attention over the decade. Executives now realize that holding excessive stocks is simply too expensive. Therefore, a great deal of effort has been expended to eliminate unnecessary inventory without compromising customer service .However, there are numerous situations where inventory simply must be held, particularly when meeting the needs of global customers. Management's goal should be to hold only what is necessary to satisfy customer requirements and manage it effectively, (ibid) Companies can monitor its inventory by looking through its financial ratios like that of monitoring receivables. Inventory turnover ratio in days (ITID) indicates the number of time the stock has been turned over sales during the period and evaluates the efficiency with which a firm is able to manage its inventory. This ratio indicates whether investment in stock is within proper limit or not (Brigham and Houston, 2003, p. 691).

Accordingly, the number of day's inventory depends upon the production as well as the sales process. Production time shall be subject to the nature of the product, the automation level as well as the technology used in the manufacturing process. Each venture must make a trade-off between faster production, the product quality and the amount of money spent to innovate the manufacturing technology. Sales usually depend on having the product ready to provide to customers upon their needs.

There are certain merits on the company earnings if reducing inventories such as decreasing warehouse space, reducing obsolete inventory, lowering depreciation, etc. In addition, there is always a deadweight cost of doing business associated with keeping inventories.

Inventory Period $=\frac{\text { Average Inventory }}{\text { CGS }} \times 365$

According to Gill et al 2010, Ching et al 2011. The empirical study shows a Higher Inventory means that Inventory is held in stock for a longer time period whilst a lower Inventory indicate that Inventory sold is more quickly . From above discussion Inventory period has negative Impact on profitability, and thus, this research also proposes the same relationship between Inventory period and profitability.

\subsubsection{Accounts Receivable Period or Number of Days of Receivable}

Sales on credit are inevitable necessity in the business world today. No business can exist without selling the products on credit. According to (Joshi, 2000) and Meyer et al (1992), noted that accounts receivables consist of the credit a business grants its customers when selling goods or services which take the form of either trade credit which the company extends to other companies or consumer credit, which the company extends to its ultimate consumers. The effectiveness of a company's credit policies can have a significant impact on its total performance. Machiraju (2005) also argue that receivables arise out of delivery of goods or rendering of services on credit. 
Receivables represent claims against others for future receipt of money, goods or services whose value depends upon the volume of credit sales and the policy for collecting such credits. Joshi (2000) indicated that the primary objective of investment in trade debtor is to increase profit by expanding sales to attract new customers and retain old customers. By constantly increasing its sales and profit the business carves out a bigger place in the market and elevates its status among competitors .In determining an optimal credit extension policy, Meyer et al (1992) observe that a company's financial managers must consider a number of major controllable variables that can be used to alter the level of receivables which include credit standards, credit terms and collection effort. Credit standards are the criteria a company uses to screen applicants in order to determine which of its customers should be offered credit and how much. The process of setting credit standards allows the firms to exercise some degree of control over the "quality" of accounts accepted. The quality of credit extended to customers is a multidimensional concept involving the time a customer takes to repay credit obligation, given that it is repaid and the probability that a customer will fail to repay the credit extended to them. In establishing credit standards, Horn (2000), suggests a means of categorizing customers for the purpose of approving or refusing credit to them. This will enable the firm to avoid investigating the credit worthiness of customers who fall into the refused category. As a basis for credit extension to those who qualify, he suggests the comparison between the expected cost of credit extension and expected profit to be forgone in the absence of credit. The literature related to credit policy is quite extensive. Srinivasan (1999) state that it is essential that companies spell out clearly and precisely the credit policy directions in writing in the general interest of the organization. The credit policy will be an adjunct to the company's marketing policy and should serve to reinforce. The decision made out of these options is based on the lowest cost. This technique is appropriate for a firm which relies to a larger extent on information obtained from experience with its own customers.

One significant revelation by Western and Copeland (1989) in the management of accounts receivable is the consequence of persistent inflation on accounts receivable. In inflationary period, when interest rates are high and financing requirement becomes large, buyers may delay their payment beyond the normal credit period. These in turn cause the selling firm's investment in account receivables to rise, increasing their financing requirement. The outcome of such a situation is the important role credit and collection policies assume in the broad spectrum of receivable management. A business should have a rational for collection of receivables. Collection policy can be tight policy which ensures better collection, fewer instances of bad debt but high collection costs. It may, however, antagonize the customers and some of them may switch to competitors. A moderate collection policy will have opposite effect Joshi (2000). Meyer et al (1992) also assert that the collection effort consist of the methods a business employs in attempting to collect payment of past-due accounts. Some commonly used methods include sending notice or letters informing the customers of the past-due status of the account and requesting payment, telephones and/or visiting the customers in an effort to obtain payment, employing a collection agency and taking legal action against the customers.

Further Companies can monitor how well accounts receivable are managed using aging schedules and financial ratios. In aging analysis, a company's account receivables are classified into different categories based on number of days they are past due after sales such as 1 to 30 days, 31 to 40 days, 41 to 50 days and so on and it helps managers to get a more detailed picture of collection efforts. The schedule can represent the receivables according to how many there are in each age group or according to the total dollars the receivables represent in each age group. Hence, the highest the number of accounts or dollars in the shortest term groups, the faster the collection or efforts are made (Fabozzi and Peterson, 2003 p. 660). Whereas, financial ratio can be used to get an overall picture of how fast credit manager collect accounts receivable. Therefore, Accounts Receivable is the length of time required to collect cash receipts (Hillier et al, 2010, p.725). That measure is also preferred as "days of sales outstanding" or "average collection period". In an ideal case, all the venture's sales will be paid in cash. The immediate receipt can minimize the time gap between the sales inflow and the outflow for product materials and labor paid out previously. However, it is practically difficult for the venture to have all sales paid in cash due to its trade credit policy or pressures from competitors. Almost ventures shall keep a certain level of accounts receivable in their daily operating, except for some businesses such as restaurants. There are some earning impacts of reducing accounts receivables such as reducing bad debt through accelerated collections. The accounts receivable period is calculated by dividing the receivables by the net sales per day. The rationale for this measure is that the company's revenue account will be booked at sales price including cost plus a profit when a sale occurs. Correspondently, if sales are made on credit, the accounts receivable account shall be recorded with the sales price. As a result, such formula can provide us an idea on how many days of sales are being supported by trade credit (Melicher \& Leach, 2009, p.183).

$$
\text { Account RECIVABLE PERIOD }=\frac{\text { Average receivable }}{\text { net sale }} \times 365
$$

This ratio measures the quality of debtors. A short collection period implies prompt payment by debtors. It reduces the chances of bad debts. Similarly, a longer collection period implies too liberal and inefficient credit collection performance. It is difficult to provide a standard collection period of debtors (Brigham and Houston, 


\section{3, p. 691}

According to Deloof and Jeger 1999; Peel et al 2000; Carcia-Tervel and Martinez -Solano 2010. A higher account receivable show that the company takes longer time to collect amount owed by customer while a shorter account receivable means that the company is able to collect amount owed by customer a faster time period. Hence, from the above discussion Account receivable has negative Impact on profitability, and thus, this research also proposes the same relationship between account receivable period and profitability.

\subsubsection{Accounts Payable Period}

There are many reasons for expecting a significant relationship between accounts payable period and company profitability. A higher value of the specifies that the company wait longer before settling suppliers and a lower value of the accounts payable period denotes the short time frame that it takes a company to pay its debts to suppliers. For a negative relationship, it has been argued that the loss of discount for early payment may affect company profitability (Ng et al. 1999). Asking time to pay means that a company must forgo the cash discount usually offered by suppliers for early payment. And, as maintained by ( $\mathrm{Ng}$ et al. 1999) the amount of cash discount can be substantial. Also, the decision to accept or request for credit period results in an inherent cost to a company, which diminishes profitability. A research by $\mathrm{Ng}$ et al (1999) indicated that the combination of the 2 per cent discount for payment within 10 days of supplies and a net period ending on 30 defines an implicit interest rate of 43.9 per cent. Therefore, the high inherent cost involved in credit period will cause a reduction in profitability. Researchers such as Padachi (2006), Deloof (2003), Garcia-Teruel and Martinez-Solano (2010b), Lazaridis and Tryfonidis (2006) and Nobanee (2009) all found a negative association between accounts payable period and profitability. For a positive relationship, it is found that credit period results in a reduction in transaction cost (Ferris 1981; Emery 1987; Petersen and Rajan 1997), thereby increasing profitability. This is because in the absence of credit period, companies may have to pay for merchandise as and when purchases are made. This would have resulted in an increase in the number of times a company has to make payment and therefore increasing the transaction cost. However, credit period allows companies to accumulate amounts owing and pay them at a period interval according to the credit period agreement, such as monthly or quarterly. Another benefit of credit period to companies as far as profitability maximization is concerned is the ability to overcome financial constraint (Schwartz 1974; Pike and Cheng 2001). One major contributing factor to company poor profitability and failure, especially SMEs is financial constraint; however, credit period serves as a financial facility to SMEs.

Due to their inherent characteristics do not get access to capital market and therefore rely on suppliers as a source of financing. This has made accounts payable an important source of short-term funds for most firms (Berger and Udell 1998; Deloof and Jegers 1999; Wilner 2000; Garcia-Teruel and Martinez-Solano 2010a). Garcia-Teruel and Martinez-Solano (2010a) maintain that accounts payable represents a source of short-term financing used by companies to finance a significant portion of firms' current assets. But, Nobaneand AlHajjar (2009a) say that a company should be careful not to harm its own credit reputation by asking too much credit from suppliers. Mathuva (2010) found a positive and highly significant association between accounts payable period and profitability, therefore maintaining that companies' profitability are enhanced when they take advantage and use suppliers' credit for working capital needs.

A positive relationship was also found by the following researchers: Falope and Ajilore (2009), Vishnani and Shah (2007), Raheman et al (2010), Sen and Oruc (2009) and Dong and Su (2010). Judging from the two spectrum of stance, it can be deduced that the benefit to companies of having a shorter accounts payable period is more than the benefit of having a lengthy accounts payable period.

Accounts Payable Period or Number of Days Accounts Payable is the length of time for which the firm is able to delay payment on the purchase of raw materials to its suppliers. It measures the average time from a purchase of materials until making actual cash payment to suppliers. Such payment delay is seen as an internal financing that helps a company to save expensive costs occurred by reaching external financing such as bank loans. However, there is a trade-off that companies should take into account in terms of damaging long-term relationships with suppliers in case of continuing payment delays. The accounts payable period is formulated by dividing the sum of trade payables by the company's cost of goods sold per day.

$$
\text { Account Payable Period }=\frac{\text { Account payable }}{\text { cost of good sold }} \times 365
$$

\subsection{Empirical evidence}

The results are quite mixed among researches. However, major studies conclude strong negative effects of inventory period (Hayajneh and Yassine, 2011; Garcia and Martinez,2007Padachi, 2006; Huynh and Su, 2010; Deloof, 2003); accounts receivable period (Gril, Biger and Mathur, 2010; Hayajneh and Yassine, 2011; Garcia and Martinez, 2007; Padachi, 2006; Huynh and Su, 2010; Deloof, 2003) and cash conversion cycle (Huynh \& Su, 2010 ; Hayajneh and Yassine, 2011; Garcia \& Martinez, 2007) whereas a positive effect of accounts payable period (Huynh \& Su, 2010) on company profitability. In contrast, there are other few studies provided totally 
different results, including positive influences of inventory period (Nobanee, 2009); accounts receivable period (Nobanee, 2009) and cash conversion cycle (Nobanee, 2009; Gril, Biger \& Mathur, 2010) whereas a negative effect of accounts payable period (Nobanee, 2009; Hayajneh \& Yassine, 2011) on company profitability. In addition, firm size (Deloof, 2003; Huynh \& Su, 2010; Padachi, 2006; Garcia \& Martinez, 2007; Hayajneh and Yassine, 2011) and sales growth (Deloof, 2003; Garcia \& Martinez, 2007; Nobanee, 2009; Hayajneh and Yassine, 2011) were all concluded to have positive influence on company profitability.

Due to the results for WCM's influence on company profitability are mixed across countries, we need to empirically investigate this influence specifically to the Ethiopia in order to provide reference for Hawassa companies on how to effectively manage their working capital for their profitability's enhancement.

To conclude, as finishing this chapter, I have equipped readers with a general background in order to further investigate my proposal. They can now understand what working capital management is about by the section 2.1; how profitability of a company can be identified in different aspects by the section 2.2; and how working capital management can influence company profitability in both theoretical and empirical basis by last section 2.3.

\section{RESEARCH METHODOLOGY}

\subsection{Description of the study area}

Hawassa is a city in Ethiopia, on the shores of Lake Hawassa in the rift valley. Located $275 \mathrm{~km}$ away from Addis Ababa to south via Debrezeit, $130 \mathrm{~km}$ east of Sodo, $75 \mathrm{~km}$ north of Dilla and $1125 \mathrm{~km}$ north of Nairobi. Hawassa is the capital city of SNNPRS and is a special zone of this region. The population of Hawassa around 380,000

Hawassa City was founded in 1952E.C during the period of Emperor Hailesilassie. Hawassa to city has got both its name and beauty from Lake Hawassa means 'wide' in sidama language: one of the widely Spoken language in the area. Now, the city and the lake share a common name i.e Hawassa. The total surface area of Hawassa City is 157.2 square kilometers; it is divided in to 8 sub -city administrations. The largest sub-city in terms of area is Hawella-Tula. Hawassa is located in southern Ethiopia, between the 7005' latitude North and 38029' longitude east. The study will be conducted at manufacturing and Merchandise company in Hawassa (Source: SNNPRS Finance and Economic Development Bureau)

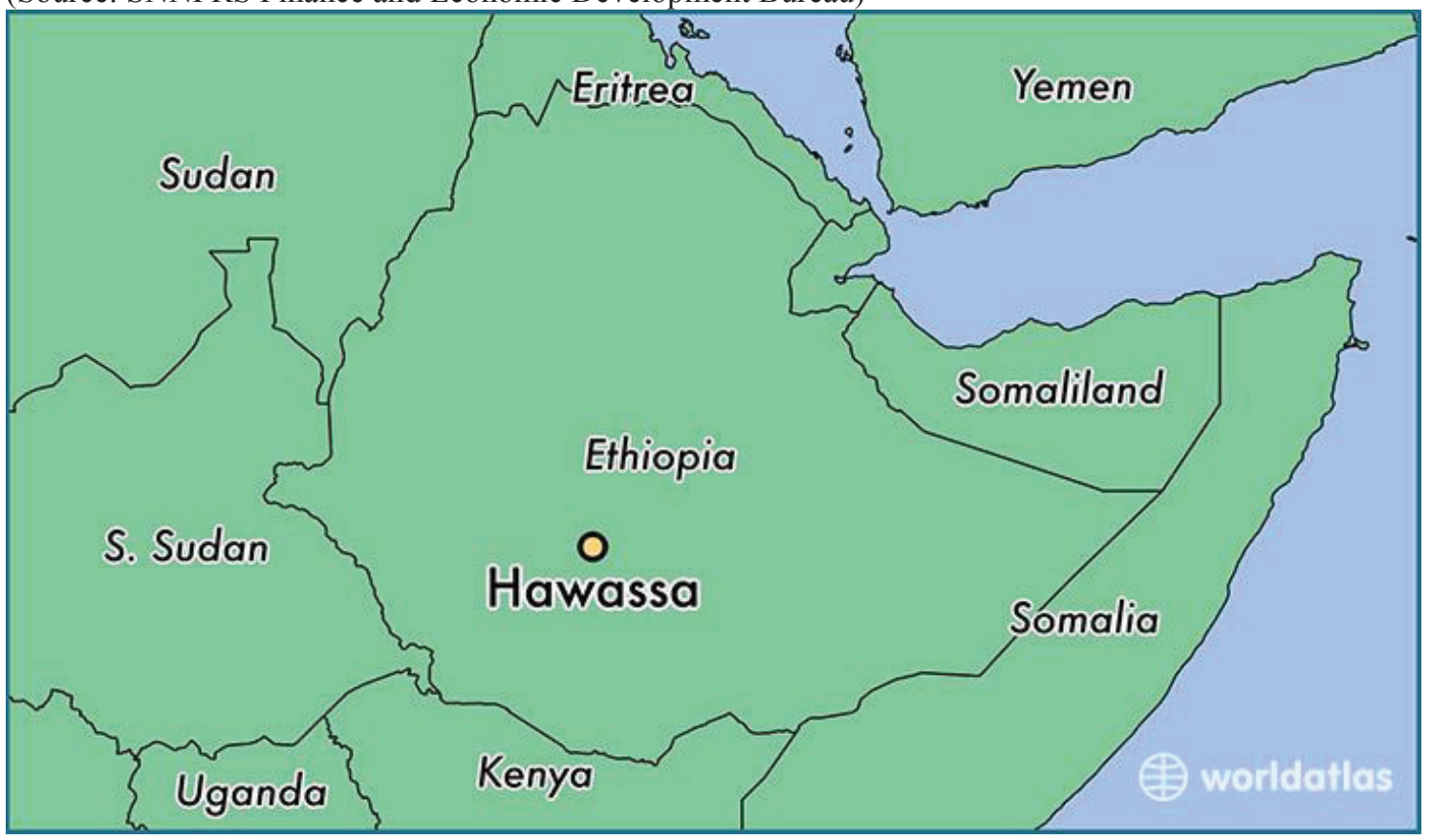

\subsection{Population of the study and Sampling procedure}

The population of this study comprise of 12 Manufacturing and 30 Merchandising companies under category "A" tax payers operating in Hawassa city Administration since 2001 E.C(2009).This is because category " A" tax payers maintain accounting record for long time, and have huge capital relative to other categories . Second the researcher has been used seven years panel data (time series data and cross-sectional data) as the objective of the study is to analyze the relationship between the stated dependent and Independent variables.

In selecting firms included in this study, convenience and purposive sampling techniques has been used .The purposive sampling method used due to the following reasons. The study first selects the different companies in both the manufacturing and Merchandising sector which have different background in terms of 
nature of their operation, capital invested, composition and need of working capital. That means, the companies don't have homogeneous background. Thus, the researcher was selected sample units via convenience sampling method.

Second, this helps avoid bias that may result from industrial classification since firms operating in different industries have different decision criteria in selecting sources of funds needed for executing investment opportunities and have different working capital requirements. To mitigate this problem the researcher has been limit the study population only to those companies engaged in manufacturing and merchandising companies in Hawaasa city Administration. The other criterion that has been used in selecting sample units to be included in the study was hold a complete 7 years financial statement data which is from 2009 to 2015. The reason for selecting to this period is due to the latest data for the investigation available for these periods.

Therefore, According to Hawassa City Administration Trade and Industry Office there are 12 manufacturing and 30 merchandise companies in the city. And the sample size consist of 5 manufacturing companies which is 43 percent of the population and 13 Merchandising companies which is 43 percent of the population.

Table 3.1 Number of Companies by Major Sector

\begin{tabular}{|l|c|}
\hline Sector & Number of Enterprise \\
\hline Manufacturing & 5 \\
\hline Merchandise & 13 \\
\hline Total & 18 \\
\hline
\end{tabular}

According to Central Limit Theory: sample size allows us to use the normal distribution, which we know a lot about, to approximate almost anything, as long as anything some requirements are met $n \geq 30$. If the random variables(Sn) is defined as the sum of independent and identically distributed random variables X1,X2,X3-----$\mathrm{Xn}$; with mean and standard deviation. Then, for large enough $(\mathrm{n} \geq 30)$ the random sample is approximately normally distributed with parameters source.

\subsection{Research Approach}

As noted by McKerchar, (2008) cited in Yesegat,( 2009), the choice among the three research approaches is guided by mainly the research problem apart from the underlying philosophy of each research methods. In this study quantitative approach has been applied to meet the overall objective of the study and to answer research hypothesis under it. In quantitative analysis, here, First: the researcher use correlation to measure the degree of relationship between different variables under consideration. Second: regression analysis has been conducted to estimate the magnitude and direction of causal relationships between the chosen dependent and independent variables.

\subsection{Data and Data Collection}

To gather the necessary data copies of audited financial statements in the form of income statement and statement of financial position over the period of 2009 to2015 has been used. Most of the required data has been collected from the financial statements submitted to the Ethiopian Revenues and Customs Authority (ERCA) in Hawassa Office and the data has been obtain directly from the respective company's financial statements.

\subsection{Variables under the study \\ 3.5.1. The dependent variable}

To measure the firm profitability, return on assets (ROA) is chosen as a dependent variable. It equals to sales minus operating expenses, divided by total assets. The rationale for that choice will be discussed in terms of why choosing the denominator as the operating income and choosing the nominator as non-financial assets. Regarding calculating the numerator of ROA, the researcher do not either use EBIT (as chosen by Padachi, 2006; Sharma \& Kumar, 2011 and Garcia-Teruel \& Martinez- Solano 2007) or net operating income (Hayajneh \& Yassine, 2011) because my main research purpose is to merely measure the effect of WCM on firm's operating profitability. Thus, the researcher tries to exclude all non-operating incomes, which would be counted in case of using net income or even EBIT. Huynh \& Su (2010); Gril, Biger \&Mathur (2010) and Lazaridis \& Tryfonidis (2006) used sales minus costs of goods sold (COGS), different from operating expenses which also include general \& administration (G\&A), selling, depreciation/amortization and other operating expenses. Deloof (2003) used sales minus cash COGS, say sales minus COGS plus depreciation/amortization expenses. Different from all others mentioned, the numerator for my dependent variable shall be sales minus all operating expenses including COGS, G\&A, selling, depreciation/amortization and other operating expenses. It is because working capital of a company is not only used for manufacturing or selling products, but also for undertaking activities to improve business operations and to remain competitive, such as activities for product development or exploring new markets, etc.As a result, all related operating expenses should be mentioned as a part of company profitability which may be influenced by WCM practices. To calculate the denominator of ROA, the researcher exclude 
financial assets in order to mitigate the participation of any financial activity from operating activity that might affect overall rate of returns (Gril, Biger \&Mathur, 2010). This choice is consistent with Gril, Biger \&Mathur (2010); Deloof (2003) and Huynh \& Su (2010).

\subsubsection{The Independent variable}

To measure the WCM's efficiency of a company, the research chooses Cash Conversion Cycle (CCC), Number of Days Inventory (IV), Number of Days Accounts Receivables (AR) and Number of Days Accounts Payables (AP) as independent variables. Those variables are seen as the most suitable proxies measuring the WCM's efficiency. Cash conversion cycle is vital because it tells us how cash is moving through a company in terms of duration. The cycle starts with a cash outflow by which the company pays back to suppliers for obtaining raw materials then ends with a cash inflow when receiving money back from its customers for selling its goods or services. In other words, the cycle indicates the number of days it takes the company to convert its operating activities requiring cash into cash returns.

If this number of days can be reduced to an optimal level which is specific to every company, then cash is returned faster to the company, increasing the its liquidity and profitability as a result. To have an optimal cash conversion cycle, companies should pay attention to managing each individual processing period effectively, say, number of days inventory, number of days accounts receivable and number of days accounts payable. Therefore, this research studies how managing those periods can influence the company's profitability. Additionally, that choice is of consistence with a majority of researches found in previous literature (Deloof, 2003; Huynh \& Su, 2010; Padachi, 2006; Garcia-Teruel \&MartinezSolano,2007;Sharma \& Kumar, 2011; Gril, Biger \&Mathur; 2010; Hayajneh \& Yassine 2011).

\subsubsection{Control variables}

The current ratio, firm size, and sales growth variables are included in the regression analysis for control purpose. The control variables are employed to measure the significance of association between variables and to determine the extent of the independent variables influence towards the dependent variables.

\section{Current Ratio (CR)}

Based on past study conducted by Sharma and Kumar (2011), current ratio has been included in the model as control variable and is computed as current assets divided by current liabilities. Other researchers that had also included current ratio as part of the control variables in the regression model (Charitou, Lois and Halim, 2012). Current ratio has been included in the model regression partly due to its role as measuring liquidity position of the firm traditionally (Zariyawati, Annuar, Taufiq and Abdul Rahim, 2009), as compared to CCC as a dynamic measurements for liquidity management (Jose, Lancaster and Stevens, 1996). Thus, the formula for computing current ratio is as follows:-

\section{Current Asset}

Current Ratio $=$

\section{Current Liabilities}

Higher current ratio is associated with lower profitability and vice versa due to the trade-off relationship between liquidity and profitability. Based on past literature view, Eljelly (2004) had found a significant negative relationship between profitability and liquidity position of firms that is computed by current ratio. Based on study conducted by Charitou, Lois and Halim (2012), there is also a negative relation reported between current ratio and profitability measured by Return on asset.

\section{Firm Size (SIZE)}

In this study, the effect of firm size on firm's profitability is also being evaluated. The purpose of including firm size in this study as a control variable is to determine the extent of firm size effect on the study of relationship between WCM and firm's profitability. Larger firms are deemed to have a positive impact on performance in view that larger firms have various capabilities and enjoy economies of scale (Falope and Ajilore, 2009; Akinlo, 2012), faced fewer information irregularity and ability to exploit market power (Akinlo, 2012; Shepherd, 1986) both in product-markets and factor-markets as compared to smaller firms which experienced limitation in obtaining financing and faced higher cost of external funding (Akinlo, 2012). However, on the other hand, larger firms also faced coordination problems which can negatively influence performance, unlike smaller firms which are simple to monitor and organized (Falope and Ajilore, 2009).

In the past study, there are several forms of definition being adopted in measuring firm size. Based on the past study conducted, the most commonly used measurements for firm size is natural logarithm of sales (Deloof, 2003; Lazaridis and Tryfonidis, 2006; Gill, Biger and Mathur, 2010; Raheman, Afza, Qayyum and Bodla, 2010) and natural logarithm of total assets (Falope and Ajilore, 2009; Nazir and Afza, 2009; Sharma and Kumar, 2011). In this study, firm size is measured based on natural logarithm of sales, as it is one of the most commonly used proxies for firm size. Furthermore, according to Raheman, Afza, Qayyum and Bodla (2010), the natural logarithm of sales has been applied in computation of size of firms, in view that it is able to lessen the heteroskedasticity and lower the effect of outliers in the regression model.

Firm Size $=$ LOG (Sale) 
Based on past literature review, Deloof (2003); Lazaridis and Tryfonidis, 2006; Raheman, Afza, Qayyum and Bodla (2010); Akinlo (2012); Charitou, Lois and Halim (2012) had found a positive relationship between firms size with the profitability of the firms, which indicates that the larger the size of the firms, the higher the firms' profitability in view of the economies of scales enjoyed that has transformed firms to higher profitability. However, on the other hand, according to Evan off and Fortier (1988) and Michael (1985), there is a negative effect of firm size on profitability in view that the positive impact on firms' profitability as a result of economies of scale might be partly offset via diversification of assets by firms, which resulted in a lesser risk and lesser return as per the portfolio theory. Therefore, based on past literature review, the expected result on the relationship between firm size and profitability may be positive or negative relationship.

\section{Sales Growth}

One of the control variables that is used in the regression by Zariyawati, Annuar, Taufiq and Abdul Rahim (2009) is (Sales1-Sales0)/Sales0 while Deloof (2003) computed sales growth as [(this year's sales -previous year's sales)/previous year's sales]. Other researchers which have also included sales growth as part of the control variables in their studies are Falope and Ajilore (2009) and Nazir and Afza (2009). Thus, in this study, sales growth is measured by the following formula: Sales Growth $=$ Sales $1-$ Sales0/Sales0

According to Akinlo (2012), sales growth is anticipated to have a positive relation with profitability in view that higher achievement in sales growth is derived as a result of better quality of product or services, lesser time required to evaluate the quality of the products, which leads to lower accounts receivables days and positive impact on profitability. The positive association between sales growth and profitability is also supported by other researchers (Deloof, 2003; Zariyawati, Annuar, Taufiq and Abdul Rahim, 2009; Raheman, Afza, Qayyum and Bodla,2010).

Based on previous researches, firm size (Deloof, 2003; Huynh \& Su, 2010; Padachi, 2006; Garcia \& Martinez, 2007; Sharma \& Kumar, 2011), sales growth (Deloof, 2003; Padachi, 2006; Garcia-Teruel \& MartinezSolano, 2007; Nobanee, 2009), and the ratio of current asset to current liablities (Afza \& Nazir, 2007) are considered as control variables.

After reading this chapter, readers are expected to see the reasons why I choose those types of data analysis to answer my problem statement and to obtain a general awareness on those statistical techniques.

Table 3.2 Variables Chooses For Study

\begin{tabular}{|c|c|c|}
\hline TYPEOFVARIABLE & NAME OF VARIABL & HOW TO MEASURE \\
\hline Dependent Variable & Return On Assets(ROA) & $\frac{\text { Net Income }}{\text { Total Asset }}$ \\
\hline \multirow{4}{*}{ Independent Variable } & Average Inventory Period(AIP) & $\begin{array}{l}\text { Average Inventory X } 365 \\
\text { Cost Of Good Sold }\end{array}$ \\
\hline & $\begin{array}{ll}\text { Average } & \text { Collection } \\
\text { Period(ACP) } & \\
\end{array}$ & $\begin{array}{l}\text { Average Receivable X } 365 \\
\text { Credit Sales }\end{array}$ \\
\hline & Average Payment Period(APP) & $\begin{array}{l}\text { Average Payment X } 365 \\
\text { Cost Of Good Sold }\end{array}$ \\
\hline & Cash Conversion Cycle(CCC) & AIP +ACP-APP \\
\hline \multirow{3}{*}{ Control Variable } & Firm Size & Log sale \\
\hline & Sales Growth & $\frac{\text { Saleof previous -Sale Current Year }}{\text { Sale Previous Year }}$ \\
\hline & Current Ratio & $\frac{\text { Current Asset }}{\text { Current Liability }}$ \\
\hline
\end{tabular}

Source: Research own work based on Literature review

\subsection{Analysis Technique}

The aim of this section is to briefly explain the various methods that has been chosen to analyze the quantitative data..The quantitative data obtained from the company has been analyzed using MS office Excel application and SPSS, and has been interpreted in percentages, tables, and graphs. The analysis of the relationship between dependent and independent variables was performed using correlation, regression method and Descriptive statistics.

\subsubsection{Descriptive statistics}

Descriptive statistics are used to describe and discuss characteristics of a data set more generally and orderly than using raw data alone. They are routinely used in reports containing a significant amount of quantitative data. These statistics are essential for using all normative and cause-and-effect statistical techniques effectively, including hypothesis testing, correlation, and regression analysis. Unless those techniques are fully grasped, data can be easily misunderstood and consequentially misrepresented (Texas State Auditor's Office, rev. 5/95). Within the context of data description, the researcher chooses mean and median to measure the central tendency 
whereas choosing standard deviation to measure dispersion of the studied sample. Measures of central tendency indicate the middle and commonly occurring points in a data set, in which mean is the average value of a data set whereas median is middle value(s) standing in this data set. Dispersion measures indicate how spread out the data is around the mean, in which standard deviation is the average difference between observed values and the mean (Texas State Auditor's Office, rev. 5/95)

\subsubsection{Correlation analysis}

The study uses Pearson correlation analysis to define the association between firm profitability and working capital management. There is a majority of previous researches have chosen to employ Pearson correlation analysis to first see the correlation between variables before conducting regression analysis(es) (Deloof, 2003; Huynh \& Su, 2010; Padachi 2006; Zariyawati, Annuar \& Abdul Rahim, 2009; Grill, Biger \& Mathur, 2010; Hayajneh, \& Yassine, 2011). However, one of the shortcomings of correlation analysis is that it cannot identify a cause-and-effect relationship. In addition, examining simple bi-variant correlation in a conventional matrix does not take into account each variable's correlation with all other explanatory variable (Padachi, 2006). It is accordingly the consequence for employing regression analyses as the next step.

\subsubsection{Regression analysis}

Literature review on regression models employed by other scholars to investigate the influence of working capital management on company profitability, other researchers have employed different regression analyses with different models. Huynh \& Su (2010) only chose Fixed Effects Model (FEM) to conduct regression analysis for investigating the effect of WCM on corporate profitability. According to them, FEM assumes firm specific intercepts which capture the effects of variables that are particular to each firm and constant over time. Different from Huynh \& Su (2010), Sharma \& Kumar (2011) selected Ordinary Least Square (OLS) as their choice for conducting regression analysis. As a combination, Deloof (2003); Garcia-Teruel \& Martinez- Solano (2007) and Padachi (2006) used both FEM and OLS to investigate the impact of WCM on corporate profitability.

The literature review shows that pooled OLS and FEM are mostly chosen to examine the effect of WCM on company profit. In the context of this thesis, I shall also choose those two types of analyses together with explaining the rationale behind my choice.

\subsubsection{Pooled Ordinary Least Square regression}

Pooled OLS regression is simply a linear regression applied to the whole data set. One of the biggest advantages of pooled OLS method is that it relaxes the restriction of an enough large data set (Schmidt 1997, 156). Therefore, with an average data set compared to other relevant studies, this regression method appears to be suitable for researcher. However, this regression is not considering different individuals across time periods. In other words, it is considering the panel nature of the dataset (Thierry, 2006-2007).Panel data, also called longitudinal data or cross-sectional time series data, are data where multiple cases (people, firms, countries, etc) are observed at different periods of time. Accordingly, data obtained in this study are classified as time series data and cross sectional data where we observe 18 different companies across seven years of research. Accordingly, another regression is additionally chosen to strengthen the research for that panel data. There are several techniques to analyze panel data, in which Fixed Effects Model or Random Effects Model (REM) are usually chosen because of their advantages.

\subsubsection{Fixed Effects Model regression}

Use FEM whenever you are only interested in analyzing the impact of variables that vary over time. FEM explore the relationship between predictor (independent) and outcome (dependent) variables within an entity (country, person, company and so forth). When using FEM, we assume that something which is time-invariant characteristics within the entity may impact or bias the predictor or outcome variables and we need to control for this. FEM remove the effect of those time-invariant characteristics from the predictor variables then we can assess the net effect of predictor variables on the outcome variable. Another important assumption of the FEM is that those characteristics are unique to the entity and should be correlated with other individual characteristics. If they are not correlated then FEM is not suitable since inferences may not be correct and you need to model that relationship by probably using REM. This is the main rationale for the Hausman (1978) test being employed (Kohler \& Frauke, 2009).

\subsubsection{Other diagnostic tests for regression models}

\section{a. Detect multi collinearity problem}

I detect multicollinearity problem by evaluating F-test estimates. Multicollinearity is a statistical phenomenon in which two or more independent variables in a multiple regression model are highly correlated. In this situation the coefficient estimates may change erratically in response to small changes in the model or the data. Multicollinearity does not reduce the predictive power or reliability of the model as a whole, at least within the sample data themselves; it only affects calculations regarding individual independent variables. That is, a multiple regression model with correlated independent variables can indicate how well the entire bundle of independent variables predicts the dependent variable, but it may not give valid results about any individual independent variable, or about which independent variables are redundant with respect to others (Farrar \& 
Glauber, 1967).

$\mathrm{F}=1 / 1-\mathrm{Rj} 2$

where $\mathrm{Rj} 2$ is the coefficient of determination of a regression of independent variable $\mathrm{j}$ on all the other independent variables. A VIF of 5 or 10 and above indicates a multicollinearity problem (O'Brien, 2007). This test was also employed by Huynh \& Su (2010) and Grill, Biger and Mathur (2010).

b. Detect and correct outliers problem

An outlier refers to an observation that is numerically distant from the rest of the data (Barnett Lewis, 1994). In regression analysis outliers can distort regression lines and coefficients (Gordon, 1998). Accordingly it can mislead the results as a consequence. Detecting and correcting outliers that violate the normality assumption is one of the most crucial statistical diagnostics for OLS regression models (Choi, 2009). Accordingly, I shall solve that problem in terms of excluding outliers by using Cook's (1977) distance statistics.

By that method, I can calculate the influence of each observation on the estimated coefficients using Cook's D. Values of Cook's $D$ that are higher than $4 / \mathrm{N}$ are considered large, where $\mathrm{N}$ is the number of observations used in the OLS regressions. Then I discard the observations that have values larger than Cook's D and re-estimate the model.

\subsection{Model specification}

The analysis of the relationship between dependent and independent variables performed using the multiple regression technique. Multiple Regression analysis help the researcher to identify to what extent the independent variable has an effect on the dependent variable. The following model has been considered:

\section{The general multiple regression models can be expressed as:}

Model 1:

ROAit $=\beta 0+\beta 1($ IVit $)+\beta 2($ LNit $)+\beta 3($ SGit $)+$ CRit $)+\eta i+\lambda I+¥ i+\varepsilon i t$

Model 2

ROAit $=\beta 0+\beta 1$ (ARit) $+\beta 2($ LNit $)+\beta 3$ (SGit) $+\beta 4($ CRit $)+\eta i+\lambda i+¥ i+\varepsilon i t$

Model 3

ROAit $=\beta 0+\beta 1($ APit $)+\beta 2($ LNit $)+\beta 3$ (SGit) $+\beta 4($ CRit $)+\eta i+\lambda i+¥ i+\varepsilon i t$

Model 4

ROAit $=\beta 0+\beta 1($ CCCit $)+\beta 2($ LNit $)+\beta 3($ SGit $)+\beta 4($ CRit $)+\eta i+\lambda i+¥ i+\varepsilon i t$

Where:

ROAit: Return on Assets of firm i in year t;

$\beta 0$ : Intercept coefficient of firm;

$\beta 1$ : Slope coefficient of independent variables (IV, AR, AP and CCC);

IVit: Inventory period of firm i in year t;

ARit: Receivables period of firm $\mathrm{i}$ in year $\mathrm{t}$;

APit: Payable period of firm i in year t;

CCCit: Cash conversion cycle of firm i in year t;

$\beta 2$ : Slope coefficient of natural logarithm of sales (LN);

LNit: Natural logarithm of sales of firm $i$ in year t;

$\beta 3$ : Slope coefficient of sales growth (SG);

SGit: Growth of sales of firm $i$ in year t;

$\beta 4$ : Slope coefficient of current asset to current liabilities, measuring current ratio of firm (CR)

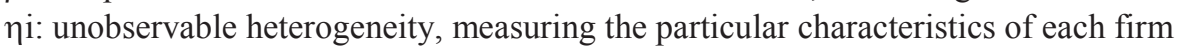

$\lambda \mathrm{i}$ : time dummy

$¥ \mathrm{i}$ : industry dummy

cit: Residual errors of firm $\mathrm{i}$ in year $\mathrm{t}$. 


\section{CONCEPTUAL FRAMEWORK}

\begin{tabular}{|c|c|c|}
\hline $\begin{array}{l}\text { Independent variables } \\
\text {-Cash conversion cycle } \\
\text {-Average collection period } \\
\text {-Inventory conversion period } \\
\text {-Average payment period }\end{array}$ & A & $\begin{array}{l}\text { Depend } \\
\text { Profitab }\end{array}$ \\
\hline & $\begin{array}{l}\text { Control variables } \\
\text {-sale growth } \\
\text {-firm size } \\
\text {-current ratio } \\
\text {-current ratio }\end{array}$ & \\
\hline
\end{tabular}

\section{Source:- Researcher's own work based on literature}

\section{RESULTS AND DISCUSSION}

\subsection{Introduction}

This chapter provides readers with the results obtained from empirical analysis which are conducted for the whole sample and for each sector. The analyses and discussion starts with trend analysis followed by correlation and regression analysis.

More importantly, the rationales behind the results are also discussed (i.e. why some effect of working capital management on company profitability are shown to be positive, why some are shown negative and even why others are demonstrated not to have any influence at all).

\subsection{Trend Analysis of the Dependent Variables}

In this sub-section the trend of the Return on Asset, over the study period (2001-2007) has been presented using graphs.

The data for the variable is presented in tabular form followed by graph of each sector and the two sector together. After the graphs is the discussion pertaining to the trend of profitability (ROA), for the stated period.

Table4.1 : Profitability data for manufacturing sector

\begin{tabular}{|l|l|l|l|}
\hline Year & Return on Asset & Change ROA & Percentage on ROA \\
\hline 2009 & 8.46 & - & - \\
\hline 2010 & -1.58 & -10.04 & -1.18 \\
\hline 2011 & 3.72 & 5.30 & 3.35 \\
\hline 2012 & 6.24 & 2.52 & 0.67 \\
\hline 2013 & 11.37 & 5.13 & 82.2 \\
\hline 2014 & 17.97 & 6.60 & 58 \\
\hline 2015 & 21.03 & 3.06 & 17 \\
\hline
\end{tabular}

Source : Researcher's own work based on Audited financial statements of the sector. 
Figure1 Graphic presentation of the trend of Return on Asset

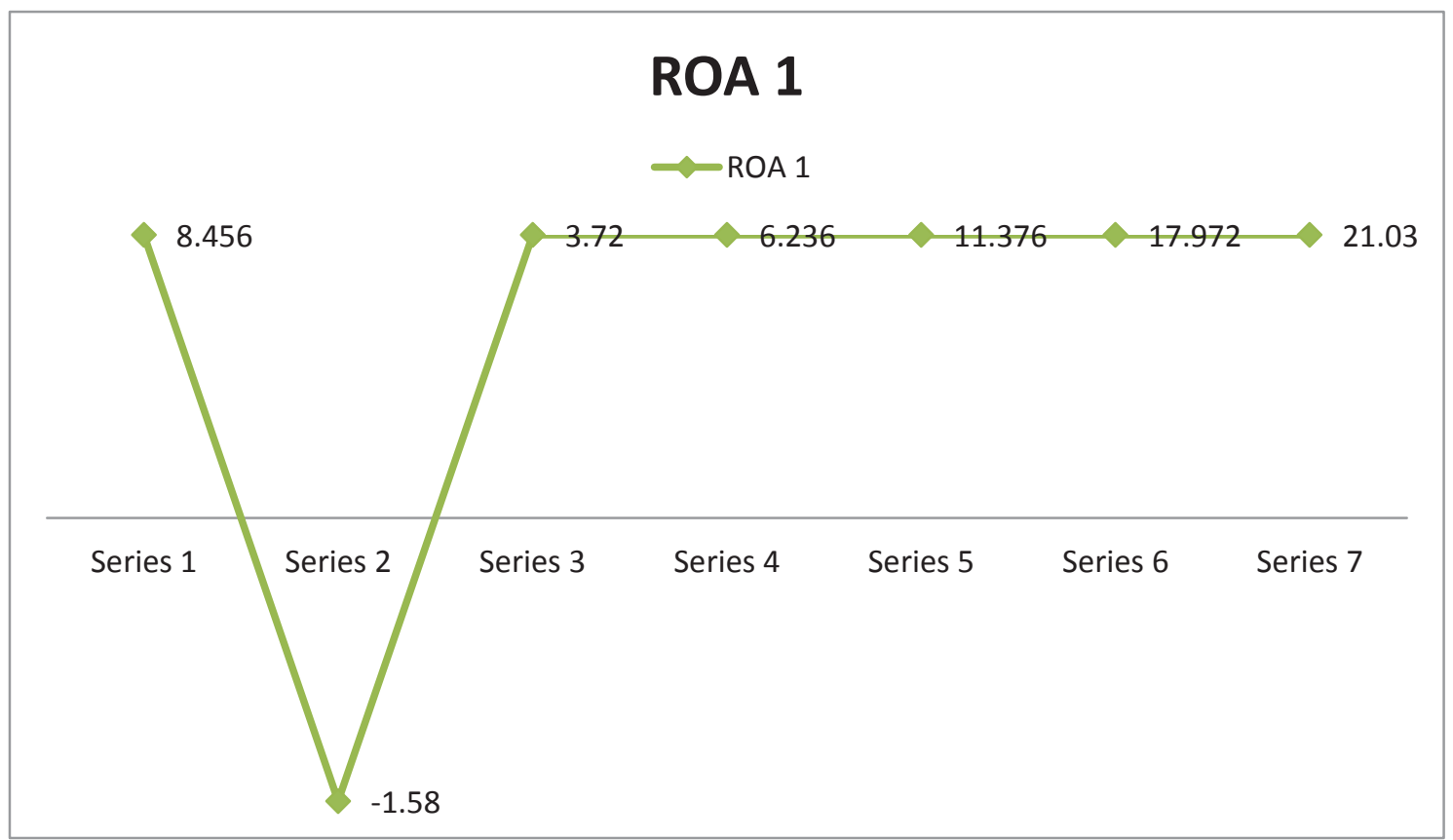

From the figure 1 the manufacturing sector profitability trend analysis shows that there is a decline in its profitability during 2010 by $3.35 \%$ which means during this period most manufacturing companies like Awassa textile factory, Awassa chip wood, and Awassa Moha Factory had held their own Inventory and Collection period increase. While after 2010 the ratio increase and constantly. The highest ROA is seen during the period 2015.

Table 4.2 : Profitability data for merchandise sector

\begin{tabular}{|l|l|l|l|}
\hline Year & Return on Asset & Change ROA & Percentage on ROA \\
\hline 2009 & 0.133 & - & - \\
\hline 2010 & 0.099 & -0.034 & -0.26 \\
\hline 2011 & 0.112 & 0.013 & 0.13 \\
\hline 2012 & 0.157 & 0.045 & 0.37 \\
\hline 2013 & 0.159 & 0.002 & 0.013 \\
\hline 2014 & 0.149 & -0.01 & $-\mathbf{0 . 0 6 3}$ \\
\hline 2015 & 0.166 & 0.11 & $\mathbf{0 . 7 4}$ \\
\hline
\end{tabular}

Source : Researcher's own work based on Audited financial statements of the sector.

Figure 3 Graphic presentation of the trend of Return on Asset

From the figure 2 it is apparent that the trend of Return On Asset during the period 2009-2010 was declining and constantly increase during the period 2010-2013. After the period 2012 -2013 the trend of Return On Asset declined and again after the period of 2013-2015 it show increase.

In general, the trend has been fluctuating. 


\subsection{Descriptive statistics}

\begin{tabular}{|c|c|c|c|c|c|c|c|c|c|}
\hline \multicolumn{10}{|c|}{ Table 4.3 descriptive statistics } \\
\hline & & IV & AR & AP & $\mathrm{CCC}$ & ROA & $\mathbf{C R}$ & SG & FS \\
\hline \multirow{5}{*}{3} & MEAN & 83.51 & 61.77 & 98.37 & 51.94 & $6.87 \%$ & & $5.05 \%$ & $35.24 \%$ \\
\hline & MEDIAM & 63.91 & 58.39 & 64.28 & 58.88 & $8.00 \%$ & & $3.00 \%$ & $33 \%$ \\
\hline & ST.DV & 95.00 & 29.91 & 113.16 & 141.66 & $24.68 \%$ & & $35.69 \%$ & $13.43 \%$ \\
\hline & MIN & 0 & .32 & 3.49 & -780.55 & $-232 \%$ & & $-100 \%$ & $7 \%$ \\
\hline & MAX & 176.86 & 194.26 & 609.70 & 976.16 & $121 \%$ & & $218 \%$ & $83 \%$ \\
\hline \multirow{5}{*}{ 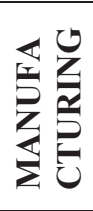 } & MEAN & 108.78 & 54.73 & 76.70 & 94.30 & $9.48 \%$ & & $6.23 \%$ & $32.67 \%$ \\
\hline & MEDIAM & 91.57 & 53.02 & 60.02 & 78.43 & $8.00 \%$ & & $3.00 \%$ & $31 \%$ \\
\hline & ST.DV & 90.53 & 21.80 & 69.31 & 99.09 & $14.42 \%$ & & $37.68 \%$ & $12.57 \%$ \\
\hline & MIN & 0 & 0 & 10.51 & -131.52 & $-1.58 \%$ & & $-75 \%$ & $100 \%$ \\
\hline & MAX & 876.86 & 166.62 & 514.50 & 976.16 & $21.03 \%$ & & $218 \%$ & $75 \%$ \\
\hline \multirow{5}{*}{ 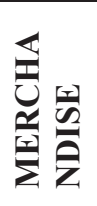 } & MEAN & 41.10 & 73.81 & 135.42 & -20.15 & $2.44 \%$ & & $3.04 \%$ & $39.59 \%$ \\
\hline & MEDIAM & 10.19 & 69.65 & 97.32 & 10.06 & $7.00 \%$ & & $2.00 \%$ & $38 \%$ \\
\hline & ST.DV & 87.20 & 37.26 & 156.39 & 171.56 & $5.57 \%$ & & $32.13 \%$ & $13.78 \%$ \\
\hline & MIN & 0 & 0 & 3.49 & -780.55 & $9.9 \%$ & & $-100 \%$ & $7 \%$ \\
\hline & MAX & 44.99 & 194.26 & 906.70 & 413.19 & $16.6 \%$ & & $174 \%$ & $83 \%$ \\
\hline
\end{tabular}

Likewise, the descriptive statistics for the four measures of efficiency of working capital management, namely, Cash conversion cycle, average accounts receivable period, average inventory conversion period and average accounts payable period are also presented in the same table.

Table 4.3 provides descriptive statistics about all variables of all manufacturing and merchandising sectors being studied. Some company zero day to order raw materials, produce and sell its product whereas it takes up to 176.86 days for other to conduct the same procedure. This is may be due to the flow in the product nature, the process level and the machinery used in the manufacturing process as well as the capacity for having products ready to provide to customers among those companies. On average, companies included in this research use 83.51 days for their inventory period and the standard deviation counts nearly 95 days. For number of days accounts receivable, .32 day is the minimum and 194.26 days is the maximum period for companies to collect trade receivable from their customers. It may explain the differences in commercial policy, competitive pressure or inefficient management among those companies.

And, it takes them 61.77 days on average to collect their cash receipts as the standard deviation of this measure is around 29.91 days. For payable period, the minimum and maximum numbers of days are 3.49 and 609.70, respectively, accounting for 113.16 days of standard deviation. Companies averagely delay paying their suppliers up to 98.37 days. For cash conversion cycle. Some company uses up 976 days whereas other exposes a negative value of -780.55 days. On average, companies take 51.94 days to complete one cycle from paying cash for materials to suppliers until collecting cash from their customers. Standard deviation of cash conversion cycle accordingly ends up 141.66 days. Regarding the values of return on assets, certain firms experience a loss in their profitability, resulting in $-232 \%$ return on assets whereas some earn a very ideal ratio of more than $100 \%$, maximum as $121 \%$. On average, firms within the scope of study can gain $6.87 \%$ return on their assets. Their sales growth accordingly ranges from $100 \%$ loss to $218 \%$ gain and ends up $5.05 \%$ on average. The ratio of current asset to current liability measures the degree of current ratio, with a higher ratio being relatively less profitability. This ratio ranges from $7 \%$ to $83 \%$ and counts $35.24 \%$ averagely.

As indicated in the result, the manufacturing sector is currently doing well with an average ROA of $9.48 \%$ and growth of sales accounts for $6.23 \%$ annually. In the mean time, we only find $2.44 \%$ ROA and $3.04 \%$ sales growth for Merchandise companies. Sales, which is used to measure firm size, is found significantly different among two sectors, say, 12,991,129 Birr for manufacturing whereas only 1,254,012 Bir for Merchandise companies on average, nearly $90 \%$ less. Moreover, the significant difference is witnessed between the minimum and maximum values within each sector. As a result, sales are then transformed into the logarithm indicator, as the proxy to measure firm size in order to avoid the presence of outliers. The degree of current ratio of those two sectors is also quite equivalent to each other, more than $60 \%$ over their total assets on average.

Regarding the cash conversion cycle, manufacturing firms has the longest number of cash conversion days, 94.30 days, but we find a negative value for those operating in merchandise with -20.15 days. To partially explain for that, we can see firms doing manufacturing job usually take a long time, 108.78 days, to order raw materials, to produce and bring their goods into the market. In contrast, it only takes Merchandise companies 41.10 days to perform such procedure because they do not need to buy materials and involve in production process. For many Merchandise firms, they do not have inventories or those stocks only account for a very small portion of total assets. However, those companies grant their customers the longest time to pay for receiving their service and also delay their payment to suppliers to the longest period as well, say, 73.81 days for accounts 
receivable period and 135.42 days for accounts payable period, respectively. This positively long cash conversion cycle was due to its long inventory period which was seven times multiplied by the very short accounts payable period. Compared with other researches, the researcher also see this problem in the study of Hayajneh \& Yassine, (2011) where the cash conversion cycle of 53 Jordanian manufacturing firms ranked from minus 1636 days to plus 1885.61 days within the period 2000-2006, or from minus 155.74 to plus 515.25 days for 1,009 Belgium firms from 1992 to 1996 (Deloof, 2003). But they did not mention how they solved their outliers in their researches. I have taken this problem into account when running my OLS regressions and correct by adding robust parameter as discussed in the Methodology part.

\subsection{Correlation analysis : Total sample}

Table 4.4 Correlation analysis both Manufacturing and Merchandise

\begin{tabular}{|c|c|c|c|c|c|c|c|c|}
\hline $\begin{array}{l}\text { VAR . } \\
\text { CR }\end{array}$ & IV & AR & & & $\mathrm{CCC}$ & ROA & FS & S G \\
\hline IV & 1.000 & & & & & & & \\
\hline$A R$ & 0.005 & 1.000 & & & & & & \\
\hline $\mathbf{A P}$ & $0.103 * *$ & $0.410 *$ & 1.000 & & & & & \\
\hline $\mathrm{CCC}$ & $0.635^{*}$ & $-0.157 *$ & $-0.601 *$ & 1.000 & & & & \\
\hline ROA & 0.078 & $-0.315^{*}$ & $-0.159 *$ & $0.109 * *$ & 1.000 & & & \\
\hline FS & -0.015 & $-0.286 *$ & $-0.285 *$ & 0.089 & $0.231 \%$ & 1.000 & & \\
\hline SG & $0.141 *$ & -0.039 & -0.050 & $0.127 *$ & 0.199* & 0.063 & 1.000 & \\
\hline CR & -0.082 & $0.138 *$ & 0.091 & $-0.149 *$ & $-0.124 *$ & $-0.116 *$ & 0.056 & 1.000 \\
\hline
\end{tabular}

*Significant level at $\alpha=5 \%, * *$ Significant level at $\alpha=10 \%$

Table 4.4 depicts the result obtained from Pearson correlation analysis for all firms dedicated to manufacturing and merchandising sectors. The result shows negative relations between firm ROA with AR and AP, respectively, with the correlation coefficients of -0.31 and -0.16 , both reaching the significant level at $\alpha=5 \%$. Those explain that allowing customers to pay back longer and/or delaying payment to suppliers longer may associate with a reduction on company profitability. The correlation analysis also results in strongly positive association between firm ROA and CCC with the coefficients of -0.11 and p-value accounts for a significant level at $\alpha=10 \%$. Accordingly, any cash conversion cycle lengthening can involve in an increase in company profitability and vice versa for $90 \%$ of the cases. The result additionally indicates a negative correlation between $\mathrm{CR}$ and firm ROA. The correlation coefficient of that relationship is -0.12 and its p-value counts 0.03 . It reaches the significant level at $\alpha=5 \%$. Given the result, the higher the company's current ratio, the lower the company's profitability and vice versa. Moreover, significantly positive correlations at level $\alpha=5 \%$ are both found for the relationships between firm ROA with FS and with SG with 0.23 and 0.20 coefficients, respectively. The indication is that the bigger the firm size and/or the annual growth of sales, the higher the firm profitability and vice verse.

The correlation matrix shows significant correlations among predictors, which can cause a problem of multicolinearity. However, the result from VIF calculations indicates that all predictors have that figure which is smaller than 4, demonstrating an absolute absence of multicollinearity between the predictors in all the regression models.

\subsection{Regression analysis}

A major weakness of Pearson Correlations is that they do not allow identifying causes from consequences. To overcome this shortcoming, the researcher use regression analysis to investigate the effect of working capital components on dependent variables: Return on Asset (ROA). The results are as presented as follow. To avoid the possibility of multicollinearity, it is important that the results from collinearity diagnostics should have tolerance value above 0.10 and variance inflation factor (VIF), which is the inverse of the tolerance value, less than 10 as the small value of tolerance indicate the high multiple correlation with other variables (Pallant, 2007, p.156). The value of $\mathrm{F}$ test explains the overall significance of a model. It explains the significance of the relationship between dependent variables and all the other independent variables. (Anderson et al., 2007)

In the case of a small sample, the adjusted R2 value should be considered as it provides more in the case of a small sample, the adjusted R2 value should be considered as it provides more accurate estimation of the true population value (Pallant, 2007, p.158). There is a rule of thumb which can be used to determine the adjust R2 value as follows: $<0.1$ : poor fit, 0.11 to 0.30 : modest fit, 0.31 to 0.50 : moderate fit, $>0.50$ : strong fit (Muijs, 2004, p. 166). To evaluate the study models, the value of R2 has been considered to determine the amount of variance in the dependent variables which is explained by all variables in the formula (Pallant, 2007, p.158). As the beta coefficients have different scales, the absolute value of Beta parameter under Standardized Coefficients is used in order to compare and determine the influence of independent variables on the dependent variable (Muijs, 2004, p. 167). The Significant value is used to measure the statistic significant unique contribution of 
each independent variable to the formula (Pallant, 2007, p.159). According to (Kohler, 1994), the values of Durbin Watson have upper limit of four and lower limit of zero. If the value of Durbin-Watson is equal to two then there exists no autocorrelation but if the value is less than two then there exists positive correlation and if the value is higher than 2 than there exist negative correlation.

In this section, regression analyses including FEM and OLS shall be employed for each sector and for the whole sample.

4.3.1 Regression results for the two sectors

Table 4.5 Regression result of total sample

\begin{tabular}{|c|c|c|c|c|c|c|c|c|}
\hline \multirow{2}{*}{$\begin{array}{l}\text { INDEPENDENT } \\
\text { VARIABLES }\end{array}$} & \multicolumn{4}{|c|}{ Fixed Effects } & \multicolumn{4}{|c|}{ Pooled OLS } \\
\hline & (1) & $(2)$ & (3) & (4) & (5) & (6) & (7) & (8) \\
\hline IV & -0.436 & & & & 0.108 & & & \\
\hline AR & & $-0.421 *$ & & & & -0.037 & & \\
\hline $\mathbf{A P}$ & & & 0.685 & & & & $-0.021 *$ & \\
\hline $\mathrm{CCC}$ & & & & -0.230 & & & & 0.0007 \\
\hline FS & $0.201 *$ & 0.197 & $0.192 *$ & $0.204 *$ & $0.013 *$ & $0.014 *$ & $0.013 *$ & $0.014 *$ \\
\hline SG & 0.022 & 0.011 & 0.018 & 0.020 & $0.131 *$ & $0.114^{*}$ & $0.116^{*}$ & $0.113 *$ \\
\hline CR & $-0.330 *$ & $-0.345^{*}$ & $-0.372 *$ & -0.350 & $-0.156^{*}$ & $-0.108 * *$ & $-0.155^{*}$ & $-0.157 *$ \\
\hline
\end{tabular}

*Significant level at $95 \% ; *$ Significant level at $90 \%$

. Source : Audited financial statement during the period 2009-2015

Test of hypothesis for whole sample

Hypothesis 1 : Inventory period has statistically significant negative effect on profitability.

Table4.6-Average Inventory Period of Coefficients ${ }^{\text {a }}$

\begin{tabular}{|l|l|l|l|l|l|}
\hline \multirow{2}{*}{ Model I } & $\begin{array}{l}\text { Standardized } \\
\text { Coefficient }\end{array}$ & \multicolumn{2}{|c|}{ Sig. } & \multicolumn{2}{l|}{ Collinearly Statics } \\
\cline { 2 - 6 } Ceta & \multicolumn{2}{|l|}{ Tolerance } & VIF \\
\hline Constant & -0.152 & -0.938 & 0.391 & & 2.954 \\
FS & -0.436 & -1.060 & 0.0033 & 0.339 & 1.778 \\
SG & 0.279 & -0.835 & 0.442 & 0.562 & 3.949 \\
CR & 0.253 & 0.508 & 0.633 & 0.2553 & 3.019 \\
\hline
\end{tabular}

$\mathrm{a}=$ Dependent Variable $=$ ROA

Source : Audited Financial Statement during the period 2009-2015

ROA=-0.152 -0.436 AIP +0.279 FS +0.253 SG -0.162CR

Table4.7 Model Summary

\begin{tabular}{|l|l|l|l|l|l|l|l|}
\hline Model & $\mathrm{R}$ & $\begin{array}{l}\mathrm{R}- \\
\text { Square }\end{array}$ & $\begin{array}{l}\text { Adjusted } \\
\text { Square }\end{array}$ & $\begin{array}{l}\text { Standard Error of the } \\
\text { Estimation }\end{array}$ & \multicolumn{2}{|l|}{ Change of Statics } & $\begin{array}{l}\text { Durbain } \\
\text { Waston }\end{array}$ \\
\hline 1 & $0.829^{\mathrm{a}}$ & 0.687 & 0.474 & 0.14107 & $\begin{array}{l}\text { F } \\
\text { Change } \\
2.195\end{array}$ & $\begin{array}{l}\text { Sig.Change } \\
\text { F } \\
0.204\end{array}$ & 2.064 \\
& & & & & \\
\end{tabular}

Source: Audited Financial Statement during the period 2009-2015.

The first Hypothesis address the relationship between Average Inventory period and Profitability (ROA). As indicate in Table 4.3 Regression analysis from FEM significant negative relationship between AIP and ROA $(\mathrm{P}<.05)$. The tolerance statistics were 0.339 and variance of Inflation factor (VIF) 2.954 for average Inventory Period. It is indicting that there were no multi- collinearity problem among the Independent variables in the model. 
The adjusted $\mathrm{R}$ square is $47.4 \%$ indicates that the stated predictors are relatively moderate predictors on ROA. The result of regression coefficient indicates that, if Inventory period decrease by one unit ROA increase by $\mathrm{B}=-0.436(\mathrm{P}<.05)$.

Additionally, firm's Return on Asset increases with increase of Firm size and sale growth but negative relationship with liquidity position of companies (current ratio).

In order to find out the autocorrelation in the residuals and in the regression, Durbian-Waston(DW) value of the model ' 1 ' was computed. Hypothesis ' 1 ' is accepted.

In other words for both manufacturing and merchandise sectors reduction in investment Inventory period will improve profitability (ROA). The regression coefficient Inventory period indicates that for every one unit reduction in IV, ROA will increase by 0.436 .

Thus, Hypothesis 1 is has been accepted based on the above analysis

Hypothesis 2 : Average collection period has statistically significant negative effect on profitability.

Table4.8 : Regression result of Average Collection Period coefficients

\begin{tabular}{|l|l|l|l|l|l|}
\hline Model 4 & $\begin{array}{l}\text { Standardize } \\
\text { Coefficients }\end{array}$ & t-value & Sig. & \multicolumn{2}{l|}{$\begin{array}{l}\text { Collinearity } \\
\text { Stastics }\end{array}$} \\
\cline { 2 - 6 } & Beta & & Tolerance & VIF \\
\hline Constant & -2.14 & -1.265 & 0.262 & & \\
CR & -0.421 & -1.070 & 0.0023 & 0.402 & 2.489 \\
SG & 0.550 & 1.589 & 0.173 & 0.521 & 1.920 \\
FS & 0.896 & 2.369 & 0.064 & 0.436 & 2.291 \\
\hline
\end{tabular}

$\mathrm{a}=$ Dependent Variable $=$ ROA

Source : Audited Financial Statement during the period 2009-2015

ROA=-2.14 -0.421ACP +0.044 FS +0.0.896 SG +0.550CR

Table 4.9 Model Summaryb

\begin{tabular}{|c|c|c|c|c|c|c|c|}
\hline \multirow[t]{2}{*}{ Model } & \multirow[t]{2}{*}{$\mathbf{R}$} & \multirow[t]{2}{*}{ R Square } & \multirow{2}{*}{$\begin{array}{l}\text { Adjusted } \\
\text { R Square }\end{array}$} & \multirow{2}{*}{$\begin{array}{l}\text { Std. Error } \\
\text { of the } \\
\text { Estimate }\end{array}$} & \multicolumn{2}{|c|}{ Change Statistics } & \multirow{2}{*}{$\begin{array}{l}\text { Durbain } \\
\text { Waston }\end{array}$} \\
\hline & & & & & F charge & $\frac{\text { Sig }}{\text { Charge } F}$ & \\
\hline 2 & $0.829^{a}$ & 0.688 & 0.512 & 0.14084 & 2.205 & 2.203 & 2.082 \\
\hline
\end{tabular}

Source : Audited Financial Statement during the period 2009-2015

The second Hypothesis address the relationship between Average Inventory Period and profitability (ROA). The Hypothesis has been tested based on the above regression result as follows:

The Tolerance statistics were 0.402 and variance of inflation factor (VIF) 2.489 for Average collection period. It indicates that there were no Multi-collinearity problem among the Independent Variables in the model.

The adjusted $\mathrm{R}$ square is $51.2 \%$. The result indicates that the independent variable consider on the model explain the dependent variable by( ROA) sector. The result of the regression coefficient shows that if Average Collection period decrease by one unit ROA increase by -0.421 .According to Pallant (2007,p.158). The adjusted $\mathrm{R}$ square $\geq 0.5$ the model is strong fit. Hence model ' 2 ' is strong fit. Additionally, firm's Return on Asset also increases with an increase in firm size and sale growth and with a decrease in liquidity position of the company. In this case, the larger the firm size, the higher benefit from economies of scale the firm can earn. This benefit importantly enhances firm's operating profitability by expanding the company's scale of production while reducing the average unit costs of production.

The Durbian-waston (D_W) results shows that 2.082 for ROA . It can be concluded that there exist no autocorrelation. Therefore, the Independence of residual Assumptions are not violated.

From the regression 2 Analysis it can be noted that ROA $(p<.05)$ statically significantly change in ACP. That is a decrease ACP will result in an increase of profitability (ROA) . For both Manufacturing and Merchandise companies if ACP decreases, it is expected that profit will increase. If cash discount is granted, even though trade receivable will decrease, cash level will increase due to the increasing cash sale, will result an increase cash balance, therefore increasing total asset. The result is consistent with major researches (Shin \&Soenen, 1998; Deloof, 2003;

Huynh \& Su, 2010; Padachi, 2006; Garcia \& Martinez, 2007) . (Shin \&Soenen, 1998; Deloof, 2003; Huynh \& Su, 2010; Padachi, 2006; Garcia \& Martinez, 2007).

Thus, Hypothesis 2 has been accepted based on the above analysis 
Hypothesis 3 : cash conversion cycle has statistically significant negative effect on profitability. The third Hypothesis address the relationship between cash conversion cycle and profitability (ROA).

Table4.10: Regression Results (For The Cash Conversion Period Coefficients ${ }^{\text {a }}$

\begin{tabular}{|c|c|c|c|c|c|}
\hline \multirow[t]{2}{*}{ Model 3} & \multirow{2}{*}{$\begin{array}{l}\text { Standardized } \\
\text { Coeffecient } \\
\text { Beta }\end{array}$} & \multirow[t]{2}{*}{$\mathbf{T}$} & \multirow[t]{2}{*}{ Sig. } & \multicolumn{2}{|c|}{ Collinearity Statistics } \\
\hline & & & & Tolerance & VIF \\
\hline Constant & 1.13 & $\begin{array}{l}-0.761 \\
\end{array}$ & 0.0048 & & \\
\hline $\mathrm{CCC}$ & -0.230 & -0.442 & 0.046 & 0.273 & 3.6693 \\
\hline $\mathbf{C R}$ & 0.530 & 1.321 & 0.024 & 0.457 & 2.186 \\
\hline SG & 0.845 & 1.593 & 0.107 & 0.262 & 3.817 \\
\hline FS & 0.088 & 0.209 & 0.843 & 0.416 & 2.404 \\
\hline
\end{tabular}

a. Dependent Variable

Source : Audited Financial Statement during the period 2009-2015

ROA $=1.13-0.230 \mathrm{CCC}+0.088 \mathrm{FS}+0.845 \mathrm{SG}+0.530 \mathrm{CR}$

Table 4. 11 Model Summary

\begin{tabular}{|l|l|l|l|l|l|l|}
\hline Model & $\mathbf{R}$ & R Square & $\begin{array}{l}\text { Adj.R } \\
\text { Square }\end{array}$ & $\begin{array}{l}\text { Std. error of } \\
\text { the Estimate }\end{array}$ & $\begin{array}{l}\text { Change } \\
\text { Static }\end{array}$ & DW \\
\hline 3 & $\mathbf{0 . 7 9 4}^{\mathrm{a}}$ & $\mathbf{0 . 6 3 1}$ & $\mathbf{0 . 2 6 2}$ & $\mathbf{0 . 1 5 3 1 6}$ & $\mathbf{1 . 7 1 0}$ & $\mathbf{2 . 1 0 3}$ \\
\hline
\end{tabular}

a. Predictors Constant, CCC,CR,FS,SG

As indicated in Table 4.3 regression analysis under FEM significant negative relation ship between CCC and profitability $(\mathrm{ROA})(\mathrm{p}<0.05)$.

The tolerance statistics 0.273 which is greater than 1 and variance of Inflation Factor (VIF) 3.699. It indicated that there is no multi-collinearity problem among the Independent variable in the model.

The adjusted $\mathrm{R}$ square is $26.2 \%$ indicating that the independent variable explain the dependent variable $26.2 \%$, which is relatively modest explanation power. The result of the regression coefficient indicates that for both manufacturing and merchandise if the CCC decrease by one unit the profitability of the companies increase by 0.230 . According to Pallant $(2007$, p.158) the Adjusted R square lies 0.11 to 0.30 modest fit.

Additionally, Firms Return on Asset also increase with firm size, sale growth and with decrease liquidity position of the company.

According to regression result, CCC statistically significantly determine the ROA. In other words when the CCC decrease by one unit the ROA increase by 0.230 .

In order to find out the autocorrelation in the residuals and in the regression, Durbin-Watson (DW) value of model 4 was computed. The result shows the value of 2.103 for ROA.

Thus, Hypothesis 3 has been accepted based on the above analysis.

Hypothesis' 5 'Average payment period has statistically significant positive effect on profitability

Table4.12: Regression Results (For The Average Payment Period) Coefficients ${ }^{\text {a }}$

\begin{tabular}{|l|l|l|l|l|l|}
\hline Model 4 & $\begin{array}{l}\text { Standardize } \\
\text { Coefficients }\end{array}$ & $\mathbf{t}$ & Sig. & \multicolumn{2}{|l|}{$\begin{array}{l}\text { Collinearity } \\
\text { Stastics }\end{array}$} \\
\cline { 2 - 6 } & Beta & & & Tolerance & VIF \\
\hline Constant & $\mathbf{- 0 . 3 9}$ & & $\mathbf{0 . 0 4 6}$ & 0.429 & 2.330 \\
CR & $\mathbf{0 . 6 8 5}$ & $\mathbf{- 2 . 3 5 5}$ & $\mathbf{0 . 0 4 3}$ & 0.454 & 2.203 \\
SG & $\mathbf{0 . 7 4 2}$ & $\mathbf{2 . 6 8 8}$ & $\mathbf{0 . 0 1 7}$ & 0.541 & 1.848 \\
FS & $\mathbf{0 . 9 1 3}$ & $\mathbf{3 . 4 9 1}$ & $\mathbf{0 . 5 0 4}$ & 0.599 & 1.669 \\
\hline
\end{tabular}

a)Dependent Variable ROA

Source : Audited Financial Statement during the period 2009-2015

ROA $=-0.39+0.685$ APP $-0.181 F S+0.913 S G+0.742 C R$ 
Table4.13 Model Summary ${ }^{\mathrm{b}}$

\begin{tabular}{|c|c|c|c|c|c|c|c|}
\hline \multirow[t]{2}{*}{ Model } & \multirow[t]{2}{*}{$\mathbf{R}$} & \multirow[t]{2}{*}{ R-Square } & \multirow{2}{*}{$\begin{array}{l}\text { Adjusted } \\
\text { R-Square }\end{array}$} & \multirow{2}{*}{$\begin{array}{l}\text { Standard } \\
\text { Error of } \\
\text { the } \\
\text { Estimate }\end{array}$} & \multicolumn{2}{|c|}{ Change Stastics } & \multirow[t]{2}{*}{ DW } \\
\hline & & & & & F-Change & Sig.Change & \\
\hline 3 & $0.905^{\mathrm{a}}$ & 0.818 & 0.637 & 0.10749 & 4.503 & 0.062 & 2.240 \\
\hline
\end{tabular}

a)Predictor Constant, APP, CR

b)Dependent Variable ROA

The fourth hypothesis address the relationship between APP and ROA .As indicated in Table 4.3 regression analysis from FEM significant positive effect between Averages payment period and profitability $(\mathrm{p}<0.05)$.

The tolerance statistics is 0.429 and variance of Inflation Factor (VIF) 2.330. It is indicates that there is no multi-collinearity problem among the Independent variables in the model.

The adjusted $\mathrm{R}$ square is $63.7 \%$ for being relatively strongest predictors of ROA. According to the regression result, APP statistically positive significant determine the profitability. In other word both manufacturing and merchandise sector if APP increase by one unit the profitability of the company also increase by 0.685 .

Different from FEM, OLS regression (7) shows a significantly negative effect of accounts payable period on firm profitability. Paying back to suppliers faster can help firms receive a certain sum of trade discounts for paying on time or even a higher amount for paying in advance. Those discount amounts can accordingly help buffer the firm profitability indirectly through operating income instead of directly through financial income in term of income received from trade discounts. The rationale could be explained similar to the ROA's increase caused by the decrease in accounts receivable period as mentioned above. In this case, the money received from trade discounts act as a potential investment in operating profit while the decrease in accounts payable are explained as the decrease in non-financial assets.

Companies can save up such free cash for making future investments in increasing their operating profit. As similar to FEM, results from OLS models also consistently indicate that firm's ROA can increase with firm size and decrease with current ratio significantly. In addition, firm profitability can also climb up with an increase in growth of sales. The rationale is that those firms which possess some advantages such as monopoly position or bargaining power thanks to growth through economies of scale, a positive relationship between growth and profitability could be explained (Külter\&Demirgüneş, 2007).

\subsubsection{Analysis for each sector}

A) Manufacturing sector

Table 4. 14 Regression Result of Manufacturing Sector

\begin{tabular}{|c|c|c|c|c|c|c|c|c|}
\hline \multirow{2}{*}{$\begin{array}{l}\text { INDEPENDENT } \\
\text { VARIABLES }\end{array}$} & \multicolumn{4}{|c|}{ Fixed Effects } & \multicolumn{4}{|c|}{ Pooled OLS } \\
\hline & (1) & $(2)$ & (3) & (4) & (5) & (6) & (7) & (8) \\
\hline IV & $-0.654^{*}$ & & & & $-0.323 *$ & & & \\
\hline $\mathbf{A R}$ & & $-0.721^{*}$ & & & & $-0.353^{\prime}$ & & \\
\hline $\mathbf{A P}$ & & & $0.524^{*}$ & & & & $0.0241 *$ & \\
\hline $\mathrm{CCC}$ & & & & $-0.047 *$ & & & & -0.011 \\
\hline FS & 0.345 & -0.028 & -0.061 & $-0.056^{*}$ & $0.013^{*}$ & $0.011^{*}$ & $0.013^{*}$ & $0.012 *$ \\
\hline SG & $0.090^{*}$ & $0.070 *$ & $0.079 *$ & $0.087^{*}$ & $0.082 *$ & $0.051^{*}$ & $0.077 *$ & $0.072 *$ \\
\hline CR & -0.044 & -0.007 & -0.043 & -0.064 & -0.052 & -0.036 & -0.051 & -0.066 \\
\hline
\end{tabular}

*Significant level at $95 \% ; *$ Significant level at $90 \%$

Source : Audited Financial Statement during the period 2009-2015 


\subsection{Test of hypotheses}

HI1 : Inventory period has statistically significant negative effect on profitability.

Table 4.15_- Regression Results Average Inventory Period of Coefficients ${ }^{\text {a }}$

\begin{tabular}{|l|l|l|l|l|l|}
\hline \multirow{2}{*}{ Model I } & $\begin{array}{l}\text { Standardized } \\
\text { Coefficient }\end{array}$ & \multicolumn{2}{|l|}{ Sig. } & \multicolumn{2}{l|}{ Collinearly Statics } \\
\cline { 2 - 2 } \cline { 5 - 6 } & Beta & \multicolumn{2}{|l}{} & Tolerance & VIF \\
\hline Constant & -1.34 & -0.083 & 0.391 & & \\
Inventory & -0.654 & -0.064 & 0.334 & 0.445 & 3.841 \\
Firms & -0.345 & -0.625 & 0.551 & 0.654 & 2.322 \\
SG & $0.090^{*}$ & 0.401 & 0.785 & 0.356 & 4.251 \\
CR & -0.040 & -0.247 & 0.657 & 0.462 & 4.141 \\
\hline
\end{tabular}

a $=$ Dependent Variable $=$ ROA

Source : Audited Financial Statement during the period 2009-2015

ROA=-1.34 -0.654IVP -0.345FS +0.090SG -0.040CR

Table 4.16 Model Summary

\begin{tabular}{|l|l|l|l|l|l|l|l|l|}
\hline Model & $\mathbf{R}$ & $\begin{array}{l}\text { R- } \\
\text { Square }\end{array}$ & $\begin{array}{l}\text { Adjusted R } \\
\text { Square }\end{array}$ & $\begin{array}{l}\text { Standard Error of } \\
\text { the Estimation }\end{array}$ & \multicolumn{2}{|l|}{ Change of Statics } & $\begin{array}{l}\text { Durbain } \\
\text { Waston }\end{array}$ \\
\hline 1 & $\mathbf{0 . 8 3 1}$ & $\mathbf{0 . 7 0 1}$ & $\mathbf{0 . 5 6 5}$ & $\mathbf{0 . 1 2 1 0 4}$ & & $\begin{array}{l}\text { F } \\
\text { Change } \\
3.245\end{array}$ & $\begin{array}{l}\text { Sig.Change } \\
\mathbf{3 . 2 4 5}\end{array}$ & $\mathbf{1 . 0 8 2}$ \\
\hline
\end{tabular}

From the analysis of the above Table4.3 Average Inventory Period has a negative association with ROA at $5 \%$ significant level and confirm null hypothesis ROA are found to be significantly related with AIP. The Adjusted R2 is $56.5 \%$ it indicates that the stated prediction power on ROA. The result of regression coefficients indicates that if IV decrease by one unit ROA increase by 0.654 the formula is moderate fit, well at predicting the Inventory conversion period and. Model 1 is fit with $\mathrm{F}$ statistics 3.245 at p-value of 0.654 ROA. It shows significance level at 5\%. The Tolerance statistics were 0.339 and the Variance Inflation Factor (VIF) 3.841 for AIP. It is indicating that there isno multi-collinearity problems among the independent variables in the data. The Durbin-Watson (DW) result shows that 1.082 for ROA. It can be concluded that there exist no autocorrelation. Therefore, the independences of residuals assumption are not violated. In model 2 , Beta coefficient is-0.654 for inventory conversion period which show that inventory conversion period makes the strong contribution to predict the dependent variable the ROA. The statistically significant are found in inventory conversion period at the 0.05 . It suggest that these variable make significant contributions to predict the dependent variable ROA.

The result from this study is in line with the initial hypothesis which states that there is significant negative relationship between inventory holding period and profitability of firms. Coefficient of Average Inventor Period is negative and $p$-value of 0.1 attached to the test statistic shows that the variable is almost significant at $10 \%$ level. This result is in line with the findings of Deloof(2003), Padachi (2006), Teruel and Solano (2007) Samiloglu and Demirgunes (2008), Lazaridis and Tryfonidis (2006), Sen and Oruc (2009), Falope and Ajilore (2009), all points out that the companies with low inventory conversion period have more efficient working capital management. The implication is that the increase or decrease inventory holding period will significantly and negatively affect profitability of the firms.

The beta coefficient for model $2 \mathrm{H} 2$ reports significant value where significant result was expected. The $p$ value less than or equal to the 0.01 significant level are reported. Thus, hypotheses has been accepted based the above regression result. 
HI2: Average collection period has statistically significant negative effect on Profitability.

Table 4.17 (Regression result Average collection period) Coeffecients ${ }^{\text {a }}$

\begin{tabular}{|l|l|l|l|l|l|}
\hline Model 2 & $\begin{array}{l}\text { Standardize } \\
\text { Coefficients }\end{array}$ & T & Sig. & \multicolumn{2}{|l|}{$\begin{array}{l}\text { Collinearity } \\
\text { Stastics }\end{array}$} \\
\cline { 2 - 6 } & Beta & & & Tolerance & VIF \\
\hline Constant & 2.57 & -0.075 & 0.321 & & \\
ACP & $-0.721^{*}$ & -0.015 & 0.314 & 0.364 & 2.82 \\
CR & -0.007 & -0.456 & 0.543 & 0.437 & 3.142 \\
SG & 0.056 & 0.234 & 0.456 & 0.521 & 3.256 \\
F-Size & 0.028 & -0.126 & 0.502 & 0.621 & 1.312 \\
\hline
\end{tabular}

a. Dependent Variable ROA

ROA=2.57 - 0.721 ACP - 0.007 CR + 0.056SG + 0.028FS

Table 4.18 Model Summary

\begin{tabular}{|c|c|c|c|c|c|c|c|}
\hline \multirow[t]{2}{*}{ Model } & \multirow[t]{2}{*}{$\mathbf{R}$} & \multirow[t]{2}{*}{ R-Square } & \multirow{2}{*}{$\begin{array}{l}\text { Adjusted } \\
\text { R-Square }\end{array}$} & \multirow{2}{*}{$\begin{array}{l}\text { Standard } \\
\text { Error of the Estimate }\end{array}$} & \multicolumn{2}{|c|}{ Change Stastics } & \multirow[t]{2}{*}{ DW } \\
\hline & & & & & F-Change & Sig.Change & \\
\hline 3 & $0.861^{\mathrm{a}}$ & 0.745 & 0.667 & 0.1345 & 4.503 & 0.062 & 2.240 \\
\hline
\end{tabular}

From the analysis the above Table 4.3 likewise inventory conversion period account receivable period has a negative association with ROA at 5\% significant level. This results that confirm null hypothesis ROA are found to be significantly related with account receivable period. The Tolerance statistics is 0.364 and the Variance Inflation Factor (VIF) 2.82 for ARP. It is indicating that there is no multi-collinearity problems among the independent variables in the data. The Adjusted R2 is $66.7 \%$ it indicates that the independent variable explain the dependent by $66.7 \%$ which is strong explanation power. Thus, Hypothesis 2 has been accepted based on the above analysis.

The result is consistent with major researches (Shin \& Soenen, 1998; Deloof, 2003; Huynh \& Su, 2010; Padachi, 2006; Garcia \& Martinez, 2007). Additionally, firm's return on assets also strongly increases with an increase in firm size measured by logarithm of sales and with a decrease in liquidity company position. Consistently, Deloof (2003), Huynh \& Su (2010), Padachi (2006) and Garcia \& Martinez (2007) all concluded the ability of firm size in increasing company profitability. In this case, the larger the firm size, the higher benefit from economies of scale the firm can earn. This benefit importantly enhances firm's operating profitability by expanding the company's scale of production while reducing the average unit costs of production.

HI3: cash conversion cycle has statistically significant negative effect on profitability.

Table 4.19 Regression result (Cash Conversion Cycle) Coefficients ${ }^{\text {a }}$

\begin{tabular}{|l|l|l|l|l|l|}
\hline \multirow{2}{*}{ Model 3 } & $\begin{array}{l}\text { Standardized } \\
\text { Coeffecient }\end{array}$ & $\mathrm{t}$ & Sig. & \multicolumn{2}{|l|}{ Collinearity Statistics } \\
\cline { 2 - 2 } \cline { 5 - 6 } & Beta & & & Tolerance & VIF \\
\hline Constant & 1.13 & -0.534 & 0.037 & & \\
CCC & -0.180 & -0.202 & 0.024 & 0.523 & 2.302 \\
SG & 0.530 & 0.421 & 0.015 & 0.457 & 3.671 \\
FS & 0.359 & 1.593 & 0.137 & 0.357 & 2.349 \\
\hline
\end{tabular}

a. Dependent Variable ROA

ROA $=1.13-0.180 \mathrm{CCC}+0.530 \mathrm{CR}+0.359 \mathrm{SG}+0.158 \mathrm{FS}$

Table4.20_Model Summary

\begin{tabular}{|l|l|l|l|l|l|l|}
\hline Model & $\mathbf{R}$ & R Square & Adj.R Square & Std. error of the Estimate & Change Static & DW \\
\hline $\mathbf{3}$ & $\mathbf{0 . 7 0 3}^{\mathrm{a}}$ & $\mathbf{0 . 5 3 1}$ & $\mathbf{0 . 3 6 5}$ & $\mathbf{0 . 1 5 3 1 6}$ & $\mathbf{2 . 3 1 0}$ & $\mathbf{2 . 1 0 3}$ \\
\hline
\end{tabular}

b. Predictors Constant, CCC,CR,FS,SG

As indicated in Table4.19 CCC has a negative association with ROA at 5\% significant level and confirm null hypothesis ROA are found to be significantly related with CCC. The Tolerance statistics were 0.523 and the Variance Inflation Factor (VIF) 2.302 for CCC. It is indicating that there is no multi-collinearity problem among the independent variables in the data.. The Adjusted R2 is 36.5\% it indicating that the independent variable 
explain the dependent variable by $36.2 \%$ which is relatively moderate explanation power. The F-statistics is used to test significant of $\mathrm{R}$, from the results, one can see that the model is fit with $\mathrm{F}$ statistics 2.310 at $\mathrm{p}$-value of 0.018 ROA. It shows highly significance level at 5\%. It can be stressed further that the significance of relationship are as the independent variable coefficient explained. This result is different from the study of Grill, Biger \& Mathur (2010), who found a positive relationship between CCC and profitability of American manufacturing firms. However, the result is in line with the findings of Hayajneh \& Yassine (2011), providing empirical analysis for Jordanian manufacturing firms.

In order to find out the autocorrelation in the residuals and in the regression, Durbin-Watson (DW) value of model 4 was computed. The result shows the value of 2.103 ROA concluded that there exist no autocorrelation in the regression ROA. Therefore, the independence of residuals assumptions are not violated. The result of the regression coefficient is -0.180 for cash conversion cycle which show that cash conversion cycle makes the last strongest contribution to predict the dependent variable the ROA. The statistically significant are found in cash conversion cycle at the 0.05 .

Thus, the third Hypothesis has been accepted based on the above analysis.

HI4: Average payment period has statistically significant positive effect on profitability.

Table 4.20 Regression Analysis(Average payment period)

\begin{tabular}{|l|l|l|l|l|l|}
\hline Model 4 & $\begin{array}{l}\text { Standardize } \\
\text { Coefficients }\end{array}$ & t-value & Sig. & \multicolumn{2}{l|}{$\begin{array}{l}\text { Collinearity } \\
\text { Stastics }\end{array}$} \\
\cline { 2 - 6 } & Beta & & & Tolerance & VIF \\
\hline Constant & -0.39 & -1.355 & 0.075 & 0.311 & 2.309 \\
CR & $0.524^{*}$ & 1.033 & 0.045 & 0.454 & 2.203 \\
SG & -0.043 & 2.915 & 0.017 & 0.643 & 2.142 \\
FS & 0.079 & 0.720 & 0.504 & 0.348 & 1.669 \\
\hline
\end{tabular}

a)Dependent Variable ROA

ROA $=-0.39-0.524-0.043 C R+0.079 S G-0.061 F S$

Table 4.21 Model Summary

\begin{tabular}{|c|c|c|c|c|c|c|c|}
\hline \multirow[t]{2}{*}{ Model } & \multirow[t]{2}{*}{$\mathbf{R}$} & \multirow[t]{2}{*}{ R-Square } & \multirow{2}{*}{$\begin{array}{l}\text { Adjusted } \\
\text { R-Square }\end{array}$} & \multirow{2}{*}{$\begin{array}{l}\text { Standard } \\
\text { Error of the Estimate }\end{array}$} & \multicolumn{2}{|c|}{ Change Stastics } & \multirow[t]{2}{*}{ DW } \\
\hline & & & & & F-Change & Sig.Change & \\
\hline 3 & $0.873^{\mathrm{a}}$ & 0.723 & 0.597 & 0.11034 & 6.713 & 0.072 & 3.401 \\
\hline
\end{tabular}

\section{a)Predictor Constant, APP, CR}

b)Dependent Variable ROA

Finally, from the analysis account payable period unlike AIP and ARP has a positive association with 0.524 ROA at 5\% significant level and confirm null hypothesis ROA are found to be significantly related with APP. The Tolerance statistics were 0.311 and the Variance Inflation Factor (VIF) 2.309 for account payable period. It is show that there were no multi-collinearity problems among the independent variables in the data. The Adjusted R2 is 59.7\% It indicates that the formula is strongest fit, good at predicting the Account payable period and. Model 5 is fit with $\mathrm{F}$ statistics 6.713 at $\mathrm{p}$-value $<0.05$ ROA. It can be concluded that there exist no autocorrelation. Therefore, the independences of residuals assumption are not violated. In model 5, Beta coefficient is 0.524 for Account Payable period which show that Account Payable period makes strongest contribution to predict the dependent variable of the ROA. The statistically significant are found in account payable period at the 0.05 . It suggest that these variable make significant contributions to predict the dependent variable ROA, The results are used to determined hypotheses stated in 1.4. The beta coefficient for model 5 H5 reports significant impact value where significant result was expected. The $p$-value less than or equal to the 0.05 significant level are reported. Where null hypotheses are confirmed and can be conclude that hypotheses5 are true.

Additionally, firm's return on assets also strongly increases with an increase in firm size measured by logarithm of sales and sale growth and with a decrease in liquidity company position. Consistently, Deloof (2003), Huynh \& Su (2010), Padachi (2006) and Garcia \& Martinez (2007) all concluded the ability of firm size in increasing company profitability. In this case, the larger the firm size, the higher benefit from economies of scale the firm can earn. This benefit importantly enhances firm's operating profitability by expanding the company's scale of production while reducing the average unit costs of production. 
B. Merchandise Sector

Table 4.21 Regression result of 13 Merchandise sector

\begin{tabular}{|c|c|c|c|c|c|c|c|c|}
\hline \multirow{2}{*}{$\begin{array}{l}\text { INDEPENDENT } \\
\text { VARIABLES }\end{array}$} & \multicolumn{4}{|c|}{ Fixed Effects } & \multicolumn{4}{|c|}{ Pooled OLS } \\
\hline & (1) & (2) & (3) & (4) & (5) & (6) & (7) & (8) \\
\hline IV & -0.011 & & & & $-0.003 *$ & & & \\
\hline AR & & $-0.027 *$ & & & & -0.001 & & \\
\hline $\mathbf{A P}$ & & & 0.012 & & & & 0.001 & \\
\hline $\mathrm{CCC}$ & & & & -0.301 & & & & -0.002 \\
\hline FZ & $0.345^{*}$ & $0.345 *$ & 0.341 * & $0.335^{*}$ & $0.026^{*}$ & $0.020 *$ & $0.021 *$ & $0.021 *$ \\
\hline SG & 0.024 & -0.024 & -0.011 & $-0.024 \%$ & $0.327 *$ & $0.327 *$ & $0.324 *$ & $0.328 *$ \\
\hline CR & $-0.954 \%$ & $-0.998 *$ & $-0.915 *$ & $-1.023 *$ & $-0.296 *$ & -0.210 & $-0.292 *$ & $-0.298 *$ \\
\hline
\end{tabular}

*Significant level at $95 \% ; *$ *Significant level at $90 \%$

Test of Hypothesis

HI1 : Inventory period has statistically significant negative effect on profitability

Table4.22 : Regression Analysis of Average Inventory Period Coeffecients ${ }^{\text {a }}$

\begin{tabular}{|l|l|l|l|l|l|}
\hline Model 2 & $\begin{array}{l}\text { Standardize } \\
\text { Coefficients }\end{array}$ & T & Sig. & \multicolumn{2}{l|}{$\begin{array}{l}\text { Collinearity } \\
\text { Stastics }\end{array}$} \\
\cline { 2 - 6 } & Beta & & & Tolerance & VIF \\
\hline Constant & 1.07 & -0.037 & 0.157 & & \\
CR & -0.011 & -0.007 & 0.214 & 0.301 & 1.320 \\
SG & -0.954 & -0.456 & 0.543 & 0.137 & 3.142 \\
F-Size & 0.024 & 0.234 & 0.456 & 0.411 & 3.321 \\
\hline
\end{tabular}

a. Dependent Variable ROA

ROA=1.07 - 0.011 AIP - 0.954 CR + 0.024SG + 0.345FS

Table4.23 Model Summary

\begin{tabular}{|c|c|c|c|c|c|c|c|}
\hline \multirow[t]{2}{*}{ Model } & \multirow[t]{2}{*}{$\mathbf{R}$} & \multirow[t]{2}{*}{ R-Square } & \multirow{2}{*}{$\begin{array}{l}\text { Adjusted } \\
\text { R-Square }\end{array}$} & \multirow{2}{*}{$\begin{array}{l}\text { Standard } \\
\text { Error of the Estimate }\end{array}$} & \multicolumn{2}{|c|}{ Change Stastics } & \multirow[t]{2}{*}{ DW } \\
\hline & & & & & F-Change & Sig.Change & \\
\hline 3 & $0.0 .671^{\mathrm{a}}$ & 0.500 & 0.045 & 0.10548 & 2.208 & 0.054 & 3.204 \\
\hline
\end{tabular}

From the analysis Table AIP has a negative association with ROA at 5\% significant level and confirm null hypothesis ROA are found to be significantly related with AIP. The Adjusted R2 is 45\% ROA. It indicates that the formula is moderate fit, well at predicting the Inventory conversion period and. Model 2 is fit with F statistics 2.208 at p-value of 0.007 ROA. It shows significance level at 5\%.The Tolerance statistics were 0.339 and the Variance Inflation Factor (VIF) 1.320 for AIP. It is indicating that there is no multi-collinearity problems among the independent variables in the data. The Durbin-Watson (DW) result shows that 3.204 for ROA . It can be concluded that there exist no autocorrelation. Therefore, the independences of residuals assumption are not violated. In model 2 , Beta coefficient is -0.373 for inventory conversion period which show that inventory conversion period makes the strong contribution to predict the dependent variable the ROA. The statistically significant are found in inventory conversion period at the 0.05 . It suggest that these variable make significant contributions to predict the dependent variable ROA.

The result from this study is in line with the initial hypothesis which states that there is significant negative relationship between inventory holding period and profitability of firms. Coefficient of Average Inventory Period is negative and $p$-value attached to the test statistic shows that the variable is almost significant at 5\% level. This result is in line with the findings of Deloof(2003), Padachi (2006), Teruel and Solano (2007) Samiloglu and Demirgunes (2008), Lazaridis and Tryfonidis (2006), Sen and Oruc (2009), Falope and Ajilore (2009), all points out that the companies with low inventory conversion period have more efficient working 
capital management. The implication is that the increase or decrease inventory holding period will significantly and negatively affect profitability of the firms.

The regression analysis from FEM shows a negative effect of Inventory on company return on asset, reaching a significant level at 5\%, policies regarding inventory management work less in affecting merchandise companies' profitability. It could be the case when Merchandise sector have a faster turnover Inventory than manufacturing sector. Merchandise purchase finished goods from it suppliers and sell it directly to the public. The product line is mostly made up low cost. Regarding results obtained from pool OLS regressions, positive effect of inventory period are found statistically significant at $5 \%$. Those results are totally different from which the researcher have found in the manufacturing sector and the whole sample. To explain for that, some Merchandise company which maintain sufficiently high inventory levels reduce costs of possible interruptions in the service supplying process. This reduces the firm's supply costs and protects them against price fluctuations of input in the market, leading to an upward trend in their operating profitability.

HI 2 Account receivable period has statistically significant negative effect on Profitability.

Table4.24 Regression Results (For The Average payment Period)

Coeffecients ${ }^{\text {a }}$

\begin{tabular}{|l|l|l|l|l|l|}
\hline \multirow{2}{*}{ Model 2 } & $\begin{array}{l}\text { Standardize } \\
\text { Coefficients }\end{array}$ & t-value & Sig. & \multicolumn{2}{|l|}{$\begin{array}{l}\text { Collinearity } \\
\text { Stastics }\end{array}$} \\
\cline { 2 - 6 } & Beta & & & Tolerance & VIF \\
\hline Constant & 1.12 & -0.048 & 1.023 & & \\
CR & $-0.027 * *$ & -0.170 & 1.291 & 0.207 & 1.203 \\
SG & -0.988 & -0.456 & 0.543 & 0.360 & 1.105 \\
F-Size & 0.024 & 0.234 & 0.456 & 0.881 & 3.001 \\
\hline
\end{tabular}

a. Dependent Variable ROA

ROA=1.12 - 0.027 ACP - 0.988 CR + 0.0SG + 0.035FS

Table4.25 Model Summary

\begin{tabular}{|l|l|l|l|l|l|l|l|}
\hline Model & $\mathbf{R}$ & R-Square & $\begin{array}{l}\text { Adjusted } \\
\text { R-Square }\end{array}$ & $\begin{array}{l}\text { Standard } \\
\text { Error of the Estimate }\end{array}$ & F-Change Stastics & DW \\
\cline { 5 - 6 } & & & $\mathbf{0 . 6 2 1}$ & $\mathbf{0 . 1 0 2 0}$ & $\mathbf{3 . 7 0 2 1}$ & $\mathbf{0 . 1 7 6}$ & $\mathbf{3 . 2 3 4}$ \\
\hline
\end{tabular}

From the analysis the above Table 4.24 likewise inventory conversion period account receivable period has a negative association with ROA at $10 \%$ significant level. This results that confirm null hypothesis ROA are found to be significantly related with account receivable period. The Tolerance statistics were 0.209 and the Variance Inflation Factor (VIF) 1.23 for ARP. It is indicating that there were no multi-collinearity problems among the independent variables in the data. The Adjusted R2 is $62.1 \%$ ROA . It indicates that the formula is strong fit, at predicting the account receivable period and Model 2 is fit with F statistics 3.702 at p-value of 1.702 ROA. It shows significance level at $10 \%$

The result is consistent with major researches (Shin \& Soenen, 1998; Deloof, 2003; Huynh \& Su, 2010; Padachi, 2006; Garcia \& Martinez, 2007). Additionally, firm's return on assets also strongly increases with an increase in firm size measured by logarithm of sales and with a decrease in liquidity company position and sales growth. Consistently, Deloof (2003), Huynh \& Su (2010), Padachi (2006) and Garcia \& Martinez (2007) all concluded the ability of firm size in increasing company profitability. In this case, the larger the firm size, the higher benefit from economies of scale the firm can earn. This benefit importantly enhances firm's operating profitability by expanding the company's scale of production while reducing the average unit costs 
H3 cash conversion cycle has statistically significant negative effect on profitability.

Table 4.26: Regression Results (For The Cash Conversion Cycle) Coefficients ${ }^{\text {a }}$

\begin{tabular}{|c|c|c|c|c|c|}
\hline \multirow[t]{2}{*}{ Model 3} & \multirow{2}{*}{$\begin{array}{l}\text { Standardized } \\
\text { Coeffecient } \\
\text { Beta }\end{array}$} & \multirow[t]{2}{*}{$\mathbf{T}$} & \multirow[t]{2}{*}{ Sig. } & \multicolumn{2}{|c|}{ Collinearity Statistics } \\
\hline & & & & Tolerance & VIF \\
\hline Constant & -1.207 & $\begin{array}{l}-0.026 \\
\end{array}$ & 0.001 & & \\
\hline $\mathrm{CCC}$ & -0.301 & -0.511 & 0.329 & 0.357 & 3.001 \\
\hline CR & -1.023 & 1.321 & 0.547 & 0.259 & 2.547 \\
\hline SG & $-0.024 *$ & 1.593 & 0.237 & 0.262 & 3.125 \\
\hline FS & $0.335^{*}$ & 0.209 & 1.814 & 0.416 & 2.619 \\
\hline
\end{tabular}

Dependent Variable ROA

ROA $=-1.207-0.301 C C C-1.023 C R-0.024 S G+0.335 F S$

4.26 Model Summary

\begin{tabular}{|l|l|l|l|l|l|l|}
\hline Model & R & R Square & Adj.R Square & Std. error of the Estimate & Change Static & DW \\
\hline 3 & $\mathbf{0 . 5 4 8}^{\text {a }}$ & $\mathbf{0 . 4 2 9}$ & $\mathbf{0 . 1 9 2}$ & $\mathbf{0 . 1 3 4 7 1}$ & $\mathbf{2 . 0 5 4}$ & $\mathbf{2 . 1 8 2}$ \\
\hline
\end{tabular}

a. Predictors Constant, CCC,CR,FS,SG

From the analysis of the above Table4.25 CCC has a negative association with ROA at 5\% significant level and confirm null hypothesis ROA are found to be significantly related with CCC. The Tolerance statistics were 0.351 and the Variance Inflation Factor (VIF) 3.001 for CCC. It is indicating that there were no multicollinearity problems among the independent variables in the data. The regression analysis from FEM shows a negative effect of Cash conversion cycle on company's return on assets, reaching a significant level at $\alpha=5 \%$. The adjusted $\mathrm{R}$ square is $19.2 \%$. In other words, $95 \%$ possibility that a decrease in cash conversion cycle shall lead to an increase in company's return on assets for all firms operating in merchandise sector

It indicates that the Model is modest fit at predicting the cash conversion cycle. The F-statistics is used to test significant of R, from the results, one can see that the model is fit with F statistics 2.054 at p-value of 0.511 ROA. It shows highly significance level at $5 \%$. So it can also be concluded that at least one of the independent variables related to ROA. It can be stressed further that the significance of relationship are as the independent variable coefficient explained.

In order to find out the autocorrelation in the residuals and in the regression, Durbin-Watson (DW) value of model 4 was computed. The result shows the value of 2.182 ROA concluded that there exist no autocorrelation in the regression ROA. Therefore, the independence of residuals assumptions are not violated. In the regression model 4 , the beta coefficient is -0.301 for cash conversion cycle which show that cash conversion cycle makes the least explanatory variable.

According to the results obtained from pool OLS regressions, positive effect of cash conversion cycle are found statistically significant. Those results are totally different from which I have found in the manufacturing sector and the whole sample. Come together the three effects together, we can explain for an increase in firm profitability due to the long cash conversion cycle.

HI4 Average Payment Period has statistically significant Positive effect on profitability.

Table 4.26 Regression Analysis result (Average payment period)

\begin{tabular}{|l|l|l|l|l|l|}
\hline Model 4 & $\begin{array}{l}\text { Standardize } \\
\text { Coefficients }\end{array}$ & t-value & Sig. & \multicolumn{2}{|l|}{$\begin{array}{l}\text { Collinearity } \\
\text { Stastics }\end{array}$} \\
\cline { 2 - 6 } & Beta & & & Tolerance & VIF \\
\hline Constant & -0.391 & & & & \\
CR & 0.012 & -1.020 & 0.357 & 0.647 & 1.201 \\
SG & -0.915 & 1.688 & 0.043 & 0.526 & 2.245 \\
FS & -0.011 & -2.193 & 0.017 & 0.541 & 3.841 \\
\hline
\end{tabular}

a)Dependent Variable ROA

ROA =-0.39 +0.012APP-0915CR-0.011SG+0.341FS 
Table 4.27 Model Summary

\begin{tabular}{|l|l|l|l|l|l|l|l|}
\hline Model & $\mathbf{R}$ & R-Square & $\begin{array}{l}\text { Adjusted } \\
\text { R-Square }\end{array}$ & $\begin{array}{l}\text { Standard } \\
\text { Error of the Estimate }\end{array}$ & Change Stastics & DW \\
\cline { 6 - 8 } & & & $\mathbf{0 . 6 h a n g e}$ & Sig.Change & \\
\hline $\mathbf{3}$ & $\mathbf{0 . 7 4 2}$ & $\mathbf{0 . 6 5 7}$ & $\mathbf{0 . 4 7 0}$ & $\mathbf{0 . 1 0 7 4 9}$ & $\mathbf{2 . 5 4 6}$ & $\mathbf{0 . 5 7 4}$ & $\mathbf{2 . 3 6 7}$ \\
\hline
\end{tabular}

a)Predictor Constant, APP, CR

b)Dependent Variable ROA

The regression analysis from FEM shows a negative effect of accounts payable period on company's return on assets, reaching a significant level at $\alpha=5 \%$. The adjusted $\mathrm{r}$ square is $47 \%$ which is relatively moderate fit. The statistical significant relationship $(\mathrm{B}=012, \mathrm{p}<.05)$. Additionally Account payable positive effect firm size, but negative effect sale growth and current ratio. From the results, It is noted that every one unit delay the payment period the firm profitability increase by 0.012 . According to the results obtained from pool OLS regressions, positive effect Account payable are found statistically significant. Moreover, accounts payable period of merchandise sector was seen to have least effect in all regressions.

Moreover, looking at the balance sheets of Merchandise companies Accounts payable in most of them occupy a pretty low proportion in total current liabilities, demonstrating that companies dedicated to this activity do not lean too much on short-term financing granted by their suppliers.

\section{SUMMARY, CONCLUSION AND RECOMMENDATION}

This chapter presents summary, conclusion drawn from the overall overviews of the research by adding the main findings of the analysis part and give future research directions

\subsection{Summary of Major Findings}

Based on the result from data analyses and discussions, the researcher has tried to summarize the major findings as follows: -

* The Trend Analysis of ROA (dependent variable) for the manufacturing companies over the study period of 2009 - to - 2015 GC shows a positive and increasing trend, reaching the pic amount of 21.03 in $2015 \mathrm{GC}$, except for a decline up to negative (-) 1.58 in $2010 \mathrm{GC}$.

On the other hand, the trend analysis of ROA for the merchandising sector shows slight fluctuation over the study period, ranging from the minimum of 0.099 in $2010 \mathrm{GC}$ up to the maximum of 0.166 in 2016 GC. Even though decline up to a negative amount was not observed, the trend showed a very small improvement in ROA over the study period.

* The result of Descriptive Statistics of the whole samples (both sectors), for the dependent and independent variables, shows the following amounts for the Mean and Standard Deviation respectively. ROA, 6.87\%, 24.68\%; AIP, 84 days, 95; ACP, 62 days, 30; APP, 98 days, 113; CCC, 52 days, 142

Whereas, the Descriptive Statistics result of manufacturing companies alone, for the dependent and independent variables shows the following amounts for the Mean and Standard Deviation respectively. ROA, 9.48\%, 14.42\%; AIP, 109 days, 91; ACP, 55 days, 22; APP, 77 days, 69; CCC, 94 days, 99.

On the other hand, the Descriptive Statistics result for the merchandising companies alone, for the dependent and independent variables shows the following amounts Mean and Standard Deviation respectively. ROA, 2.44\%, 5.57\%; AIP, 41 days, 87; ACP, 74 days, 37; APP, 135 days, 156; CCC, 20 days, 172.

* The Pearson-Correlation result for the whole samples (both sectors) shows that, AIP and CCC have a positive correlation with the dependent variable (ROA); while ACP and APP have a negative correlation with the dependent variable (ROA), at a significance level of $5 \%$ for all dependent variables, except CCC which is at $10 \%$ level of significance.

* For the manufacturing companies, results from the two Regression Models (FEM and Pooled OLS) used in this study shows that, AIP, ACP and CCC have significant negative impacts on the dependent variable (ROA), and on contrary, APP has a significant positive impact on the dependent variable (ROA) at a confidence level of 95\% (except for AIP and CCC under Pooled OLS model, with unknown \& 90\% level of confidence respectively).

* For the merchandising companies, Regression result from FEM shows that, AIP, ACP and CCC have negative impacts on the dependent variable-ROA, (with ACP-having significant impact at $90 \%$ confidence level) and on contrary APP has a significant positive impact on the dependent variableROA, at a confidence level of $95 \%$.

On the other hand, Regression result from Pooled OLS model shows that, AIP, ACP and CCC have negative impacts on the dependent variable-ROA, (with AIP \& CCC-having significant impact) at a $95 \%$ confidence level and on contrary, APP has a positive impact on the dependent variable-ROA. 
* Based on the results from the t-test, conducted to test the hypothesis on each study variable, all of the alternate hypotheses are accepted. Because, the $(\mathrm{t})$ values are found to be significant for all.

\subsection{CONCLUSION}

Working capital plays a vital role in the company's operations and requires the efficient management. The management of working capital concerns the management of cash, inventories, accounts receivable and accounts payable. It is necessary for a company to monitor its working capital properly and maintain its balance at the appropriate level. Shortage of working capital may lead to lack of liquidity as well as loss of production and sales; on the contrary, excess balance of working capital could be seen as loss of investment opportunities.

To conclude, the expectation on the signs of effect of working capital management component is now partially met. Manufacturing sector is seen to mostly meet that expectation. In this sector, inventory period and cash conversion cycle were found to have negative effect on company profitability in both Fixed Effects and Ordinary Least Square regressions while accounts receivable period was seen to negatively affect the company profitability, witnessed by Ordinary Least Squares regressions. Differently, Merchandise firms only had accounts receivable period to negatively impact the company profitability as expected in Fixed Effects regressions. In the mean time, inventory period and cash conversion cycle were both found to have positive influences on profitability in Ordinary Least Square regressions.

Moreover, accounts payable period of merchandise sector was seen to have no effect in all regressions.

\subsection{RECOMMENDATIONS}

The study has shown a clear understanding of working capital components and they influence firm performance. This promotes the efforts of managers to improve their companies' profitability which can be done through appropriate management of working capital components. Thus, management should intensify initiatives to encourage greater understanding and acceptance of working capital components that boosts financial performance in the Hawassa manufacturing and merchandise sector. In order to boost the wealth of manufacturing and merchandise companies, management should Endeavour to find and employ a viable working capital composition that increases firms' Profitability. Therefore, based on the major Findings of the study the following recommendations are made of the research were premised on the study findings as follows:

* The trend analysis of ROA (the dependent variable) for merchandising companies shows a positive, but slightly fluctuating trend over the study period. However, the levels of ROA over the study period shows very small amounts as compared to the manufacturing companies. Therefore, merchandising companies should work hard on WCM to improve their ROA levels. The AIP for manufacturing companies shows a long period (109 days) relative to the merchandising sector, which in turn affects their CCC unfavorably. Therefore, this sector should focus on reducing AIP thereby improving its CCC

* The AIP for manufacturing companies shows a long period (109 days) relative to the merchandising sector, which in turn affects their CCC unfavorably. Therefore, this sector should focus on reducing AIP thereby improving its CCC.

* Further, the researcher recommended that, the manufacturing companies; marketing, purchasing and production departments should have create strong linkage and communications so as to feed each other in their firms' operations and minimize costs.

The findings shows that, average payment period has positive related to manufacturing firms' profitability. The researcher recommended that even if late payments have their own advantage to increase the profitability of the firm, manufacturing firms' have to pay their debts on time that not losing their venders in the long run.

\section{Reference}

Afzar and Nazer (2008) Effect of working capital management on Profitability 23, 156-163

Arnold( 2008) Financial Management Analysis (p, 176)

Brigham, E. F., Houston, J. F. (2003),Fundamentals of Financial Management (10th Edition ed.)

Deloof, M., (2003),Does Working Capital Management Affect Profitability of Belgian Firms? Business Finance \& Accounting, 30, 573-587.

Fabozzi Frank, j. and Peterson Pamela P., 2003, "Financial management and analysise, 2nd ed,

Falope, O. I., and Ajilore, O. T. (2009), Working Capital Management and Corporate Profitability: Evidence from Panel Data Analysis of Selected Quoted Companies in Nigeria. Research Journal of Business Management, 3(3), 73-84

Hillier, D., Ross, S., Westerfield, R., Jaffe, J. and Jordan, B., Corporate Finance,

John Wiley and Sons, Inc., publisher, New Jersey Canada. Financial Management. Spring, pg. 32-41

K.S. Vataliya PRACTICAL(2009). FINANCIALACCOUNTING (Advance Methods,- Techniques \& Practices.) Lamberson, M. (1995).Changes in Working Capital of Small Firms In Relation To Change Economic Activity 
Mid-American Journal of Business, 10(2), 45-50

Lazaridis, D., \&Tryfonidis.(2006). Relationship between Working Capital Management and Profitability of Listed Companies in the Athens Stock Exchange.

Marx, K. (1867).Das Capital, Gateway Edition (2000), Washington DC: Regnery Publishing.

McGraw-Hill, 2010, 1stEuropean edition p145-160.

Melicher, R.W. and Leach, J. C., Finance for entrepreneurs, McGraw-Hill, 2009, 3rdedition.

Padachi, K. (2006).Trends in Working Capital Management and its Impact on Firms' Performance.

Paramasivan, C. and Subramanian, T. 2009, 'Financial management ${ }^{\text {ee }}$, Published by New Age"

Pass, C. \& Pike, R., (1987).Management of Working Capital: a Neglected Subject.

Raheman, A., and Nasr, M., Working capital management and profitability-case of Pakistani firms. International Review of Business Research Papers 3(1), 2007, 279-300. Shin,H.H and L. Soenen, 1998. Efficiency of working capital and corporate profitability. Finance practice and education, 8,37-45

Vishnani, S., \& Shah, B. K. (2007).Impact of Working Capital Management Policies on Corporate Performance-An Empirical Study. Global Business Review, 8(2), 267-281.

Wajahat A \& Syed Hammad Ul Hassan(2010) Relationship Between The Profitability And Working Capital Policy Of Swedish Companies:Master thesis, UMEA university.

Wang, Y.J., (2002).Liquidity Management, Operating Performance, and Corporate Value: Evidence from Japan and Taiwan. Journal of Multinational Financial Management, 12: 159-169

\section{Appendix}

List of Companies

\begin{tabular}{|l|l|l|l|}
\hline NO. & COMPANY NAME & SECTOR & CURRENCY UNIT \\
\hline 1 & Admass Flour Factory & Manufacture & ETB \\
\hline 2 & Awassa Flour Factory & Manufacture & ETB \\
\hline 3 & Awassa Chip wood Factory & Manufacturing & ETB \\
\hline 4 & Awassa Moha Factory & Manufacturing & ETB \\
\hline 5 & Awassa Textile Factory & Manufacturing & ETB \\
\hline 6 & Addis Tesfa P.L.C & Merchandise & ETB \\
\hline 7 & Amena Yasin P.L.C & Merchandise & ETB \\
\hline 8 & Delina P.L.C & Merchandise & ETB \\
\hline 9 & Kedir P.L.C & Merchandise & ETB \\
\hline 10 & Ketera P.L.C & Merchandise & ETB \\
\hline 11 & Meskeren P.L.C & Merchandise & ETB \\
\hline 12 & Tsehay Boreje P.L.C & Merchandise & ETB \\
\hline 13 & Samuel Tadesse & Merchandise & ETB \\
\hline 14 & Selam P.L.C & Merchandise & ETB \\
\hline 15 & Usman P.L.C & Merchandise & ETB \\
\hline 16 & Yohannes Shumete P.L.C & Merchandise & ETB \\
\hline 17 & Y.D P.L.C & Merchandise & ETB \\
\hline 18 & Zelalem Tadesse P.L.C & Merchandise & ETB \\
\hline
\end{tabular}

